\title{
The imprint of stratospheric transport on column-averaged methane
}

\section{The imprint of stratospheric transport on \\ column-averaged} methane

A. Ostler et al.

A. Ostler ${ }^{1}$, R. Sussmann ${ }^{1}$, P. K. Patra ${ }^{2}$, P. O. Wennberg ${ }^{3}$, N. M. Deutscher ${ }^{4,5}$, D. W. T. Griffith ${ }^{4}$, T. Blumenstock ${ }^{6}$, F. Hase ${ }^{6}$, R. Kivi ${ }^{7}$, T. Warneke ${ }^{5}$, Z. Wang $^{5}$, M. De Mazière ${ }^{8}$, J. Robinson ${ }^{9}$, and H. Ohyama ${ }^{10, a}$

${ }^{1}$ Karlsruhe Institute of Technology, IMK-IFU, Garmisch-Partenkirchen, Germany

${ }^{2}$ Research Institute for Global Change, JAMSTEC, Yokohama, 236-0001, Japan

${ }^{3}$ California Institute of Technology, Pasadena, USA

${ }^{4}$ University of Wollongong, New South Wales, Wollongong, Australia

${ }^{5}$ Institute of Environmental Physics, University of Bremen, Bremen, Germany

${ }^{6}$ Karlsruhe Institute of Technology, IMK-ASF, Karlsruhe, Germany

${ }^{7}$ Finnish Meteorological Institute, Arctic Research Center, Sodankylä, Finland

${ }^{8}$ Belgian Institute for Space Aeronomy, BIRA-IASB, Brussels, Belgium

${ }^{9}$ National Institute of Water and Atmospheric Research, NIWA, Omakau, New Zealand

${ }^{10}$ Earth Observation Research Center, EORC, Aerospace Exploration Agency, JAXA, Tsukuba, Japan

a now at: Solar-Terrestrial Environment Laboratory, Nagoya University, Nagoya, Japan

Title Page

14 
Received: 19 June 2015 - Accepted: 4 July 2015 - Published: 28 July 2015

Correspondence to: A. Ostler (andreas.ostler@kit.edu)

Published by Copernicus Publications on behalf of the European Geosciences Union.

ACPD

15, 20395-20447, 2015

The imprint of

stratospheric

transport on

column-averaged methane

A. Ostler et al.

Title Page

Abstract

Conclusions

Tables

14

Back

Full Screen / Esc

Printer-friendly Version

Interactive Discussion
Introduction

References

Figures

$>$ I

$>$

Close 


\section{Abstract}

Model simulations of column-averaged methane mixing ratios $\left(\mathrm{XCH}_{4}\right)$ are extensively used for inverse estimates of methane $\left(\mathrm{CH}_{4}\right)$ emissions from atmospheric measurements. Our study shows that virtually all chemical transport models (CTM) used for this 5 purpose are affected by stratospheric model-transport errors. We quantify the impact of such model transport errors on the simulation of stratospheric $\mathrm{CH}_{4}$ concentrations via an a posteriori correction method. This approach compares measurements of the mean age of air with modeled age and expresses the difference in terms of a correction to modeled stratospheric $\mathrm{CH}_{4}$ mixing ratios. We find age differences up to $\sim 3$ years yield model simulations and ground-based $\mathrm{XCH}_{4}$ observations from the Total Carbon Column Network (TCCON) reveal that stratospheric model-transport errors cause biases in $\mathrm{XCH}_{4}$ of $\sim 20 \mathrm{ppb}$ in the midlatitudes and $\sim 27 \mathrm{ppb}$ in the arctic region. Improved overall as well as seasonal model-observation agreement in $\mathrm{XCH}_{4}$ suggests that the proposed, age-of-air-based stratospheric correction is reasonable.

The latitudinal model bias in $\mathrm{XCH}_{4}$ is supposed to reduce the accuracy of inverse estimates using satellite-derived $\mathrm{XCH}_{4}$ data. Therefore, we provide an estimate of the impact of stratospheric model-transport errors in terms of $\mathrm{CH}_{4}$ flux errors. Using a onebox approximation, we show that average model errors in stratospheric transport correspond to an overestimation of $\mathrm{CH}_{4}$ emissions by $\sim 40 \%\left(\sim 7 \mathrm{Tgyr}^{-1}\right)$ for the arctic, $\sim 5 \%\left(\sim 7 \mathrm{Tgyr}^{-1}\right)$ for the northern, and $\sim 60 \%\left(\sim 7 \mathrm{Tgyr}^{-1}\right)$ for the southern hemispheric mid-latitude region. We conclude that an improved modeling of stratospheric transport is highly desirable for the joint use with atmospheric $\mathrm{XCH}_{4}$ observations in atmospheric inversions.
ACPD

15, 20395-20447, 2015

\section{The imprint of stratospheric transport on \\ column-averaged methane \\ A. Ostler et al.}

\section{Title Page}

\section{Abstract}

Conclusions

Tables

14

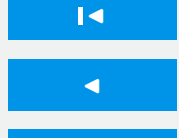

Back
Introduction

References

Figures

DI
Close

Full Screen / Esc

Printer-friendly Version

Interactive Discussion 


\section{Introduction}

The global budget of $\mathrm{CH}_{4}$ is driven by emissions from the Earth's surface and chemical loss in the atmosphere. While the dominant sink due to hydroxyl radicals $(\mathrm{OH})$ is commonly regarded as stable over a long time period (Montzka et al., 2011), the sources of $5 \mathrm{CH}_{4}$ exhibit high variability in their spatial and temporal distribution (Dlugokencky et al., 2009; Nisbet et al., 2014). Methane emissions are estimated by top-down approaches on the basis of chemical transport models (CTMs) constrained by atmospheric measurements. Required a priori information about the distribution of emissions and sinks is often provided by bottom-up approaches. Both, top-down and bottom-up estimates

10 have been used to assess and to explain changes of the global $\mathrm{CH}_{4}$ budget in the past (Kirschke et al., 2013). Recently, top-down inversions have increasingly benefitted from newly available satellite remote sensing measurements (Bergamaschi et al., 2013; Fraser et al., 2013, 2014; Monteil et al., 2013; Houweling et al., 2014; Wecht et al., 2014; Cressot et al., 2014; Alexe et al., 2015; Turner et al., 2015) covering large geographical areas where surface observation networks lack in density, such as the tropical lands. In contrast to in situ observations, mostly performed at the surface, satellite retrievals of column-averaged dry-air $\mathrm{CH}_{4}$ mixing ratios $\left(\mathrm{XCH}_{4}\right)$ contain information about the complete $\mathrm{CH}_{4}$ vertical distribution. The stratospheric contribution relative to the $\mathrm{CH}_{4}$ total column only is $\sim 5 \%$ at the tropics but increases up to $\sim 25 \%$ at midand high latitudes. This implies that CTMs have to account for both stratospheric and tropospheric chemistry and transport when using satellite $\mathrm{XCH}_{4}$ retrievals for optimizing fluxes. Although the modeling of stratospheric transport has been improved, it still remains a challenging task for CTMs with a focus on the simulation of tropospheric tracers such as $\mathrm{CH}_{4}$. As a result of errors in the model transport parameterizations, stratospheric $\mathrm{CH}_{4}$ distributions simulated by various models show significant differences, especially in the lower stratosphere (up to $~ 50 \%$ between the models) (Patra et al., 2009b).
ACPD

15, 20395-20447, 2015

\section{The imprint of stratospheric transport on \\ column-averaged methane \\ A. Ostler et al.}

\section{Title Page}

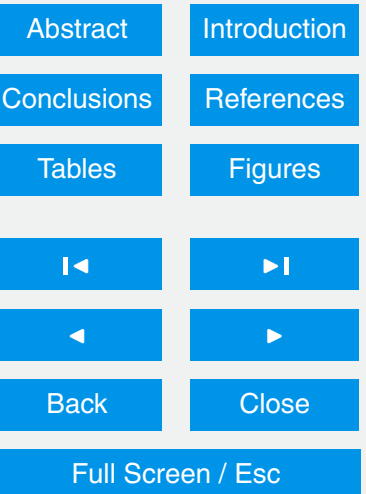

Printer-friendly Version

Interactive Discussion 
A clear separation between systematic model errors and systematic measurement errors is a central problem, since inversion-estimated fluxes are obtained by minimizing model-measurement residuals (Fraser et al., 2013; Houweling et al., 2014; Turner et al., 2015). Efforts to determine fluxes from satellite-derived $\mathrm{XCH}_{4}$ have used different 5 strategies to account for ill-defined residual biases where most of the bias corrections are based on ad hoc latitudinal functions. For example, a recent $\mathrm{CH}_{4}$ inversion study removes a high-latitude bias by fitting a quadratic regression to the latitudinal distribution of model-measurement $\mathrm{XCH}_{4}$ residuals (Turner et al., 2015). In this context, the latitudinal bias is attributed to errors in either the satellite observations or the modeled

10 stratospheric $\mathrm{CH}_{4}$ without an unambiguous assignment. This suggests, that a precise description of stratospheric model errors is needed. Therefore, the goal of this study is (i) to better understand the sensitivity of $\mathrm{XCH}_{4}$ to the details of simulated stratospheric transport and (ii) to estimate the impact of stratospheric model-transport errors in terms of emissions.

The paper has the following structure: after introducing the models (Sect. 2) and the observations (Sect. 3), we present the stratospheric correction in Sect. 4. Results from the comparison between model and TCCON data are shown in Sect. 5. Section 6 shows that the impact of stratospheric model-transport errors on stratospheric $\mathrm{CH}_{4}$ can be converted into $\mathrm{CH}_{4}$ emissions. Section 7 contains a summary and conclusions.

\section{Model simulations}

In order to analyse the relationship between stratospheric $\mathrm{CH}_{4}$ and stratospheric transport, we use model simulations of $\mathrm{CH}_{4}$ and of mean age - a well-known diagnostics for stratospheric transport (Waugh and Hall, 2002).

\section{ACPD}

15, 20395-20447, 2015

\section{The imprint of stratospheric \\ transport on \\ column-averaged \\ methane \\ A. Ostler et al.}

\section{Title Page}

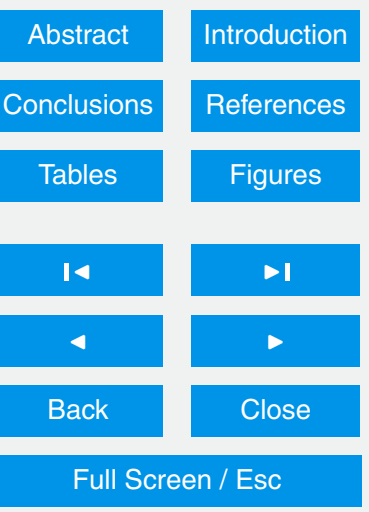

Printer-friendly Version

Interactive Discussion 


\subsection{ACTM}

The main part of our analysis is based on simulations from a state-of-the-art CTM: the Center for Climate System Research/National Institute for Environmental Studies/Frontier Research Center for Global Change (CCSR/NIES/FRCGC) atmospheric 5 general circulation model (AGCM) based CTM (hereafter, ACTM). ACTM simulations of $\mathrm{CH}_{4}$ were provided with a horizontal resolution of T42 spectral truncation $\left(\sim 2.8^{\circ} \times 2.8^{\circ}\right)$ with 67 sigma-pressure levels in the vertical (surface $-90 \mathrm{~km}$ ). The modeled meteorology from ACTM is nudged towards the fields of Japan Meteorological Agency Reanalysis (JRA) data products.

10 Tropospheric $\mathrm{OH}$ concentrations are predefined and scaled to match global methyl chloroform $\left(\mathrm{CH}_{3} \mathrm{CCL}_{3}\right)$ decay rates (Spivakovsky et al., 2000). Stratospheric OH distributions are used from the full stratospheric chemistry model version of the ACTM along with a monthly mean climatology of chlorine (Cl) (Takigawa et al., 1999). The O ( $\left.{ }^{1} D\right)$ concentrations are calculated in ACTM. Comparisons of ACTM-simulated $\mathrm{SF}_{6}$ with atmospheric measurements demonstrate that the modeled transport fairly captures synoptic and seasonal variations in tropospheric transport as well as interhemispheric exchange (Patra et al., 2009a). Additionally, the modeled NH/SH OH ratio of 0.99 is in line with $\mathrm{CH}_{3} \mathrm{CCL}_{3}$ observations (Patra et al., 2014). As a consequence, the accurate model description of tropospheric transport and photochemical removal of $\mathrm{CH}_{4}$ leads to realistic vertical and interhemispheric $\mathrm{CH}_{4}$ gradients in the troposphere (Saito et al., 2013).

Emission distributions correspond to the control scenario used by the TransCOM $\mathrm{CH}_{4}$ intercomparison study (Patra et al., 2011). The prior $\mathrm{CH}_{4}$ fluxes includes interannually varying anthropogenic emissions, based on annual mean $1^{\circ} \times 1^{\circ}$ maps from the Emission Database for Global Atmospheric Research (EDGAR; version 3.2/FT) (Olivier and Berdowski, 2001) and cyclostationary natural emissions, based on the GISS inventory (Fung et al., 1991). Emission data are extrapolated for the years after 2008. The photochemical removal of $\mathrm{CH}_{4}$ in the troposphere and stratosphere is sim-
ACPD

15, 20395-20447, 2015

\section{The imprint of stratospheric \\ transport on \\ column-averaged \\ methane \\ A. Ostler et al.}

\section{Title Page}

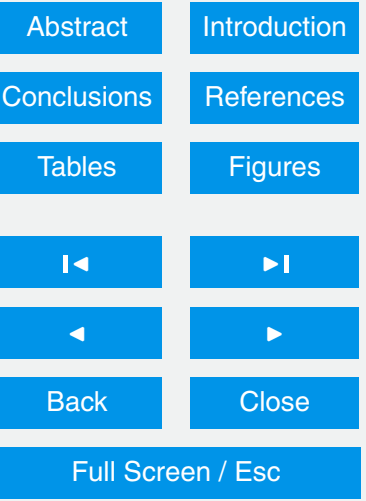

Printer-friendly Version

Interactive Discussion 
ulated by ACTM via reactions involving $\mathrm{OH}, \mathrm{Cl}$, and $\mathrm{O}\left({ }^{1} \mathrm{D}\right)$ along with recommended temperature-dependent reaction and wavelength-dependent photolysis rates (Sander et al., 2006; Patra et al., 2011).

Besides the simulation of $\mathrm{CH}_{4}$, ACTM provides distributions of the mean age of 5 stratospheric air to analyze transport in the troposphere and stratosphere. Mean age is calculated as the difference between surface and upper air concentrations normalized by the concentration increase rate at the surface using a Green's function method (Hall and Plumb, 1994). The latter is estimated from the simulation of an idealized transport tracer with uniform surface fluxes, linearly increasing trend, and no loss in the atmo-

\subsection{TransCOM models}

The chemistry-transport model intercomparison experiment (TransCom- $\mathrm{CH}_{4}$ ) is a comparison between $\mathrm{CH}_{4}$ simulations from twelve CTMs with a special focus on the role of surface emissions, transport, and chemical loss (Patra et al., 2011). For this study we analyzed model simulations from six selected TrancCom CTMs: ACTM (Patra et al., 2009a, b, 2011, 2014), GEOS-Chem (Pickett-Heaps et al., 2011; Fraser et al., 2011), LMDZ (Hourdin et al., 2006), NIES08i (Belikov et al., 2011), TM5 (Krol et al., 2005), and TOMCAT (Chipperfield, 2006). Note that the TransCom version of ACTM uses meteorological products from the National Centers for Environmental Prediction (NCEP)

and hence differs from the ACTM version used in this study. We derived mean age distributions via sulfur hexafluoride $\left(\mathrm{SF}_{6}\right)$ model simulations for all $\mathrm{CTMs}_{\text {. }}$ As $\mathrm{SF}_{6}$ is a chronological tracer, stratospheric mean age was calculated as the difference between $\mathrm{SF}_{6}$ mixing ratio at the tropical tropopause and stratospheric $\mathrm{SF}_{6}$ mixing ratio normalized by the tropospheric growth rate of $\mathrm{SF}_{6}$ at the tropics.
ACPD

15, 20395-20447, 2015

\section{The imprint of stratospheric \\ transport on \\ column-averaged}

methane

A. Ostler et al.

\section{Title Page}

\section{Abstract}

Conclusions

Tables

14

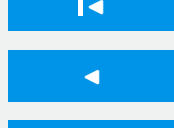

Back
Introduction

References

Figures

DI
Full Screen / Esc

Printer-friendly Version

Interactive Discussion 


\section{Observational datasets}

In addition to model simulations, observations of mean age and $\mathrm{XCH}_{4}$ are used to evaluate both the accuracy of stratospheric model transport and the sensitivity of $\mathrm{XCH}_{4}$ to stratospheric model transport.

\section{3.1 Mean age}

Mean age data was inferred from vertical profiles of $\mathrm{SF}_{6}$ measured by balloon-borne cryogenic air sampler. The observed mean age dataset used in the current study consists of 7 vertical profiles of $\mathrm{SF}_{6}$ obtained at three different locations in the Northern Hemisphere $(\mathrm{NH})$ at altitudes between 17 and $37 \mathrm{~km}$ (see Table 1). One profile was pre10 sented in Patra et al. (1997), the remaining profiles are part of the study from Harnisch et al. (1996).

\subsection{TCCON}

Solar absorption measurements in the near-infrared (NIR) are performed via groundbased Fourier Transform Spectrometers (FTS) at TCCON sites across the globe.

15 TCCON-type measurements are analyzed with the GGG software package including the spectral fitting code GFIT to derive total column abundances of several trace gases (Wunch et al., 2011). The $\mathrm{CH}_{4}$ total column is inverted from the spectra in 3 different spectral windows centered at 5938,6002 , and $6076 \mathrm{~cm}^{-1}$. The spectral fitting method is based on iteratively scaling a priori profiles to provide the best fit to the measured spectrum. The general shape of the a priori profiles has been inferred from aircraft, balloon and satellite profiles in order to provide a realistic interhemispheric gradient. In addition, the shape of the daily a priori profile is stretched vertically depending on tropopause altitude and the latitude of the measurement site. $\mathrm{XCH}_{4}$ is calculated by dividing the $\mathrm{CH}_{4}$ total column by the simultaneously measured dry-air pressure column.

ACPD

15, 20395-20447, 2015

\section{The imprint of stratospheric transport on \\ column-averaged methane \\ A. Ostler et al.}

\section{Title Page}

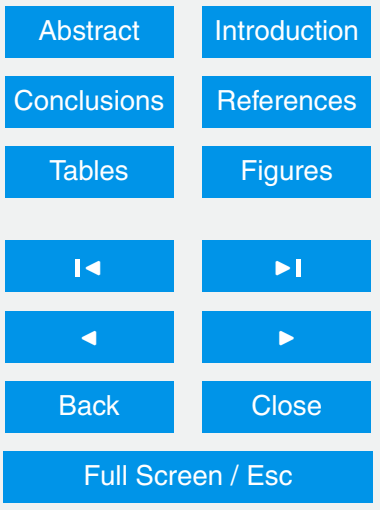

Printer-friendly Version

Interactive Discussion 
These $\mathrm{XCH}_{4}$ retrievals are a posteriori corrected for known airmass-dependent biases and calibrated to account for airmass-independent biases which can among other errors arise from spectroscopic uncertainties. The airmass-independent calibration factor is determined by comparisons with coincident airborne or balloon-borne in situ 5 measurements over TCCON sites (Wunch et al., 2010; Messerschmidt et al., 2011; Geibel et al., 2012). Although the absolute accuracy of $\mathrm{TCCON} \mathrm{XCH}_{4}$ retrievals is calibrated to in situ measurements on WMO scale, it can still be affected by additional systematic uncertainties. However, the quality of the retrievals is continuously improved by correcting the influence of systematic instrumental changes over time. As a re10 sult of these improvements there are different versions of the GGG software package. In this study we use TCCON retrievals performed with version GGG2014 (for details see https://tccon-wiki.caltech.edu/). The TCCON measurement precision for $\mathrm{XCH}_{4}$ is $\sim 0.3 \%$ for single measurements.

TCCON data were obtained from the TCCON Data Archive, hosted by the Carbon 15 Dioxide Information Analysis Center (CDIAC: http://cdiac.ornl.gov/). The individual data sets of the TCCON sites used in this study are available at this database (Blumenstock et al., 2014; Deutscher et al., 2014; Griffith et al., 2014a, b; Hase et al., 2014; Kawakami et al., 2014; Kivi et al., 2014; de Mazière et al., 2014; Sherlock et al., 2014a, b; Sussmann et al., 2014; Warneke et al., 2014; Wennberg et al., 2014a, b).

\section{Stratospheric correction}

Inaccurate model transport in the stratosphere implies errors in the description of stratospheric $\mathrm{CH}_{4}$ and, hence, errors in simulated $\mathrm{XCH}_{4}$. In order to correct these model errors, we perform a two-step correction. We first correct modeled mean age and subsequently use the corrected mean age to adjust stratospheric $\mathrm{CH}_{4}$.

\section{ACPD}

15, 20395-20447, 2015

\section{The imprint of stratospheric transport on \\ column-averaged methane \\ A. Ostler et al.}

\section{Title Page}

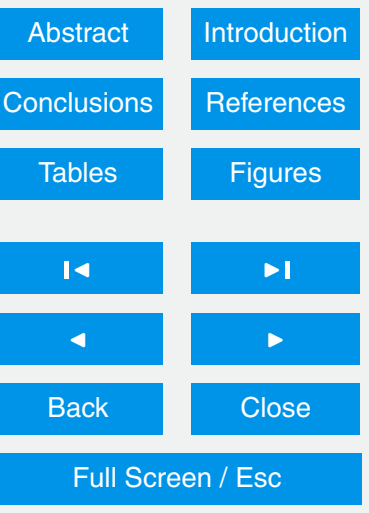

Printer-friendly Version

Interactive Discussion 


\subsection{Stratospheric model-transport error}

Recently, Miyamoto et al. (2013) compared ACTM-modeled age of air with ages inferred from $\mathrm{SF}_{6}$ observations presented in Sect. 3.1. They obtained correction factors at each $\mathrm{SF}_{6}$ profile location and interpolated these factors to all model grid cells be5 tween the equator and the North Pole. The mirror image was used for the $\mathrm{SH}$. Applying the correction factors to the modeled age produces distributions of corrected age. Both the original and the corrected model distribution of mean age correspond to climatological monthly mean distributions.

We detect stratospheric model-transport errors as the difference between original 10 and corrected model distributions of age. Zonal annual means of original age (Fig. 1a) and corrected age (Fig. 1C), as well as the corresponding age differences (Fig. 1e) provide evidence that ACTM underestimates the age in the lower stratosphere (50$100 \mathrm{hPa}$ ) by up to $\sim 3$ years, with the magnitude of the error increasing poleward. In general, the magnitude of the modeled age is lower compared to the corrected age 15 and the shape of age isopleths differs.

\subsection{Adjustment of $\mathrm{CH}_{4}$ simulations}

To account for the impact of model-transport error on stratospheric $\mathrm{CH}_{4}$ we applied an a posteriori correction to the modeled $\mathrm{CH}_{4}$ mixing ratio profiles $x$. The correction method is based on expressing the stratospheric mixing ratio of long-lived tracers in terms of the (corrected) age of air (Г). According to Volk et al. (1997) the following Taylor expansion can be used for chemically active tracers in the vicinity of the tropopause $\left(\Gamma=\Gamma_{\mathrm{tp}}, \boldsymbol{x}=\boldsymbol{x}_{\mathrm{tp}}\right)$ :

$\boldsymbol{x}(\boldsymbol{\Gamma})=\boldsymbol{x}_{0}\left[1-\beta_{0} \boldsymbol{\Gamma}-\gamma_{0} \boldsymbol{\Gamma}+\beta_{0} \gamma_{0}\left(\boldsymbol{\Gamma}^{2}+2 \boldsymbol{\Delta}^{2}\right)\right]$

\section{The imprint of stratospheric transport on}

column-averaged methane

A. Ostler et al.

\section{Title Page}


where

$\beta_{0}=-\left.\frac{1}{\Gamma_{\text {tp }}} \frac{\mathrm{d} x}{\mathrm{~d} \boldsymbol{\Gamma}}\right|_{\Gamma_{\mathrm{tp}}}$

is the normalized gradient of $x$ with respect to age at the tropopause and $\Delta$ is the width of the age spectrum. The normalized average growth rate $\gamma_{0}$ reflects the increase in 5 tropospheric $\mathrm{CH}_{4}$. Eq. (1) describes the decline of stratospheric $\mathrm{CH}_{4}$ due to three contributions: $(A)$ chemical loss, $(B)$ tropospheric growth, and $(C)$ interaction of chemistry and growth. For our correction of $\mathrm{CH}_{4}$ mixing ratios we found that term $(A)$ is predominant in particular within the lower stratosphere. Terms $(B)$ and $(C)$ have minor contributions within the upper stratosphere (see Fig. A1).

10 The chemical loss of $\mathrm{CH}_{4}$ in terms of age (i.e. $\beta_{0}$ ) was derived from the original $\mathrm{CH}_{4}$ model profiles. The linear tropospheric trend $\left(\Gamma_{0}\right)$ was estimated to be $6 \mathrm{ppbyr}^{-1}$ since the beginning of the year 2006, which on average is in agreement with recent trend studies (Dlugokencky et al., 2009; Sussmann et al., 2012). The width of the age spectrum $\Delta$ was parameterized in terms of $\Gamma$ as $\Delta^{2}=1.25 \mathrm{yr}(\Gamma+0.5 \mathrm{yr})$ according to an 15 approximation obtained from GCM simulations (Volk et al., 1997). Since modeled and the corrected ages differ only above the tropopause, the position of the tropopause can be determined easily. Applying the corrected age of air to Eq. (1) yields the corrected stratospheric $\mathrm{CH}_{4}$ mixing ratios.

It is important to note that we did not explicitly account for interannual variability 20 in age since we used monthly mean distributions, which can be regarded as climatological distributions. Therefore, our stratospheric correction of $\mathrm{CH}_{4}$ concentrations could be affected by uncertainties due to interannual variability. However, these errors cancel out in the column's ratio of corrected and modeled age. This ratio is implicitly contained in the predominant chemical loss term $\beta_{0} \Gamma$. Minor seasonal errors in upper stratospheric mixing ratios might result from tropospheric growth (term B) and mixed growth-chemistry (term $\mathrm{C}$ ), but cause a small impact on $\mathrm{XCH}_{4}$ given the relative contribution of the upper stratospheric $\mathrm{CH}_{4}$ to the total column. Trends in stratospheric age 20405

The imprint of stratospheric transport on

column-averaged methane

A. Ostler et al.

\section{Title Page}

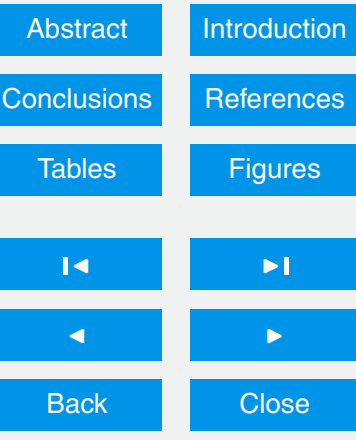

Full Screen / Esc

Printer-friendly Version

Interactive Discussion 
are not considered as they are still under debate (Engel et al., 2009; Mahieu et al., 2014).

Applying the stratospheric correction to original ACTM simulations of $\mathrm{CH}_{4}$ yields "age-corrected" model $\mathrm{CH}_{4}$ distributions (ACTMac). Figure $1 \mathrm{f}$ shows differences be5 tween zonal $\mathrm{CH}_{4}$ distributions of ACTM (Fig. 1b) and ACTMac (Fig. 1d). These $\mathrm{CH}_{4}$ differences between original and corrected stratospheric $\mathrm{CH}_{4}$ mixing ratios are minimal at the tropics and increase towards high latitudes with maxima in the lower stratosphere (up to $250 \mathrm{ppb}$ ). Furthermore, the model errors in stratospheric $\mathrm{CH}_{4}$ depend on season; i.e., the correction of stratospheric $\mathrm{CH}_{4}$ has a seasonal component with maximum 10 in winter-time and minimum in summer (see Fig. A2).

\section{Results from validation of the model correction}

In the following, we compare original model simulations (ACTM) with model simulations where we have corrected for errors in the simulated stratospheric $\mathrm{CH}_{4}$ (ACT$\mathrm{Mac})$. As we are interested in the impact of the stratospheric model-transport error on ${ }_{15} \mathrm{XCH}_{4}$, both model datasets are evaluated by TCCON XCH${ }_{4}$ retrievals from selected sites (see Table 1). For this reason, vertical $\mathrm{CH}_{4}$ model distributions were extracted for each TCCON site, interpolated to the time of measurement, and converted to $\mathrm{XCH}_{4}$. The comparison with TCCON XCH${ }_{4}$ retrievals (GGG2014 release) is performed by accounting for the TCCON retrieval a priori and vertical sensitivity. The evaluation of the stratospheric model-transport error is based on the statistical analysis of modelmeasurement differences. Mean differences (bias) and residual standard deviations (RSD) were calculated from $\mathrm{XCH}_{4}$ residual time series for each TCCON site. We distinguish between mean and seasonal bias components. The overall bias is derived from the deseasonalized $\mathrm{XCH}_{4}$ time series, whereas the seasonal bias is obtained from the

\section{The imprint of stratospheric transport on}

column-averaged methane

A. Ostler et al.

\section{Title Page}

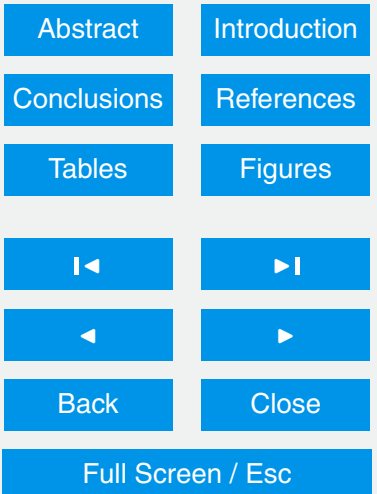

Printer-friendly Version

Interactive Discussion 


\subsection{Global effects in $\mathrm{XCH}_{4}$}

Figure 2a shows that the overall bias between ACTM and TCCON in the NH increases with latitude. At subtropical sites (Izaña, Lamont), the bias is $10.2 \mathrm{ppb}$; at mid-latitude sites (Karlsruhe, Garmisch, Park Falls, Orléans, Białystok), the bias is $\sim 25 \mathrm{ppb}$. The 5 bias increases up to $\sim 36.7 \mathrm{ppb}$ at high latitudes (Sodankylä). In contrast, at tropical sites (Darwin, Reunion), we find a negative bias $(-11.5,-6.6 \mathrm{ppb})$. In the Southern Hemisphere $(\mathrm{SH})$, the bias at the subtropical site Wollongong $(-2.0 \mathrm{ppb})$ and the midlatitude site Lauder $(-8.1 \mathrm{ppb})$ is smaller compared to the $\mathrm{NH}$. The biases at all midlatitude sites as well as at the high-latitude site are significant on $2 \sigma$ confidence level. Regarding the high values of the bias in the $\mathrm{NH}$ (the region with the majority of anthropogenic emissions), one might conjecture that this latitude-dependent bias is caused by emissions not correctly considered in the a priori flux distribution of the model. However, such biases for ACTM simulation and in situ measurements are not observed in the troposphere (Saito et al., 2013). Instead, the bias is much smaller between ACT-

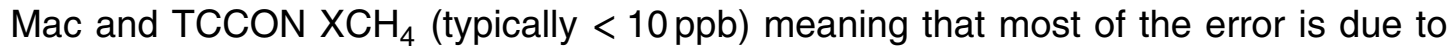
poor description of stratospheric $\mathrm{CH}_{4}$ in ACTM. With ACTMac, there is no significant bias at mid-latitude and arctic TCCON sites (the accuracy of TCCON is estimated to be $\sim 4 \mathrm{ppb}$; Wunch et al., 2010). Only in the SH at the tropical site Reunion (-10.3 ppb) and the subtropical site Wollongong $(-11.5 \mathrm{ppb})$ we still find significant negative biases.

The overall impact of the stratospheric model-transport error on $\mathrm{XCH}_{4}$ is illustrated by the difference of the biases derived from ACTM and ACTMac, respectively (Fig. 2c). The bias difference increases from $\sim 1 \mathrm{ppb}$ at the tropical site Darwin up to $\sim 27 \mathrm{ppb}$ at the arctic site Sodankylä. It is obvious that the latitude-dependent error originates from the latitude-dependent age differences, which created latitude-dependent differences between the modeled $\mathrm{CH}_{4}$ distributions, i.e., ACTM - ACTMac (Fig. 1).

\section{The imprint of stratospheric transport on column-averaged methane \\ A. Ostler et al.}

\section{Title Page}

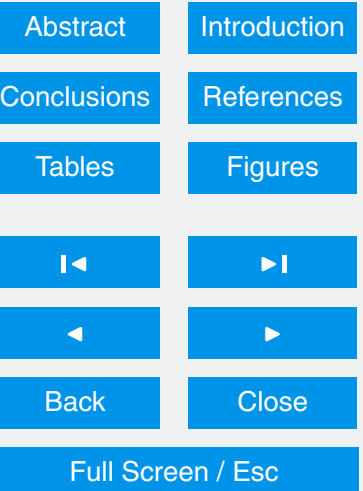

Printer-friendly Version

Interactive Discussion 


\subsection{Seasonal effects in $\mathrm{XCH}_{4}$}

We quantify seasonal effects in terms of RSD as a proxy for seasonal bias. In contrast to the mean bias, the seasonal bias does not show a strong latitude-dependence (Fig. 2b). E.g. sites of similar geographical latitude (Garmisch, Karlsruhe, Orléans, and 5 Park Falls) differ in the corresponding RSD values. However, the seasonal biases at sites in the $\mathrm{NH}$ are somewhat larger $(\sim 6-8 \mathrm{ppb})$ than in the $\mathrm{SH}(\sim 4-6 \mathrm{ppb})$. ACTM has been shown to provide a realistic description of the $\mathrm{NH} / \mathrm{SH} \mathrm{OH}$ ratio (Patra et al., 2014), therefore this $\mathrm{NH}-\mathrm{SH}$ difference may be caused by higher $\mathrm{NH}$ emissions (and prior emission errors).

10 We find that the agreement between model and TCCON $\mathrm{XCH}_{4}$ is generally improved

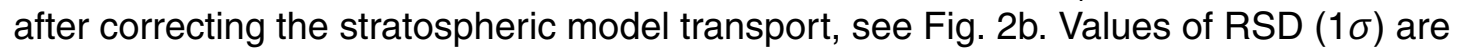
reduced and range from $\sim 3$ to $\sim 5 \mathrm{ppb}$, except for the sites Darwin and Saga. At Darwin, an above-average RSD is not surprising since there is high interannual variability due to monsoon periods. The impact of stratospheric transport on the seasonal bias 15 is shown in the difference of RSD values obtained from ACTM and ACTMac, respectively. As in the case of the annual-mean effects, for the seasonalities we also see a latitude-dependent difference with increasing magnitude at high latitudes (Fig. 2d). The improved seasonal agreement between model and TCCON $\mathrm{XCH}_{4}$ is a result of seasonal differences between modeled and corrected age, which produce seasonal differences in the corresponding stratospheric $\mathrm{CH}_{4}$ distributions (Fig. 1).

To illustrate the impact of stratospheric transport on mean seasonal variations of the $\mathrm{CH}_{4}$ budget, we calculated climatological (period: 2008-2013) mean seasonal cycles from model and TCCON XCH${ }_{4}$ time series, respectively. The mean seasonal $\mathrm{XCH}_{4}$ cycle from ACTM and ACTMac are different at mid-latitude and polar sites (Figs. 3a, b and B1). At subtropical sites, the modeled mean seasonal cycles are very similar to each other, but ACTMac shows better agreement with TCCON (Fig. 3c). Almost no differences between ACTMac and ACTM are found at the tropics (Darwin, Reunion). Remaining differences between ACTMac and TCCON are likely to be caused by erro-
ACPD

15, 20395-20447, 2015

\section{The imprint of stratospheric \\ transport on \\ column-averaged \\ methane \\ A. Ostler et al.}

\section{Title Page}

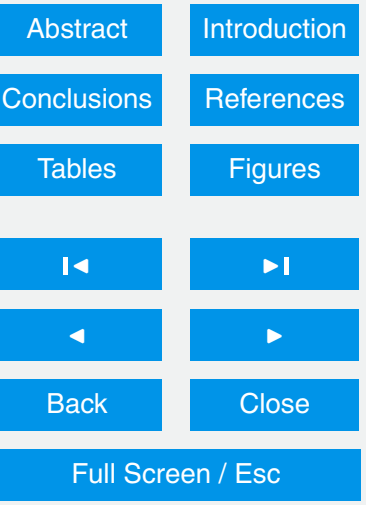

Printer-friendly Version

Interactive Discussion 
neous model prior emissions. Apart from that, the improved model-observation agreement as a result of the stratospheric correction is also confirmed by a climatological comparison of stratospheric $\mathrm{CH}_{4}$ derived from model simulations and stratospheric satellite observations (see Appendix C).

5 Finally, the latitude-dependent impact of model errors in stratospheric transport on $\mathrm{XCH}_{4}$ is twofold: it is determined by the magnitude of the model bias in stratospheric $\mathrm{CH}_{4}$ as well as by the magnitude of the stratospheric airmass (tropopause height). As both contributions depend on latitude, the impact of stratospheric model-transport errors on $\mathrm{XCH}_{4}$ is increasing poleward. Moreover, the stratospheric model-transport

\section{Impact of stratospheric model-transport errors on global $\mathrm{CH}_{4}$ budget}

Stratospheric model-transport errors are not unique to ACTM: we also analyzed stratospheric transport for five other well-established CTMs (Sect. 2.2) and found that these CTMs are affected by a similar latitude-dependent transport error (Figs. D1 and D2). 15 After validating the correction of stratospheric model transport, we now estimate the impact of the poor description of stratospheric $\mathrm{CH}_{4}$ in a CTM on inverting $\mathrm{CH}_{4}$ fluxes for the assumption that no ad hoc latitudinal bias correction would be applied to account for the latitudinal $\mathrm{XCH}_{4}$ bias between model-observation residuals. The model $\mathrm{CH}_{4}$ distribution is converted into a global $\mathrm{CH}_{4}$ burden $\left[\mathrm{CH}_{4}\right]$. The stratospheric correction yields a burden difference $\left[\Delta \mathrm{CH}_{4}\right]$ between global burdens from the original and the corrected CTM. A change in the global burden corresponds to a change, $\Delta E$, in the source strength assuming a constant sink. Consequently we quantify the impact of the stratospheric error in terms of emissions, $\Delta E$, using a one-box model for the whole atmosphere (Dlugokencky et al., 1998). The annual $\mathrm{CH}_{4}$ source strength $(E)$

\section{ACPD}

15, 20395-20447, 2015

\section{The imprint of stratospheric \\ transport on \\ column-averaged}

methane

A. Ostler et al.

\section{Title Page}

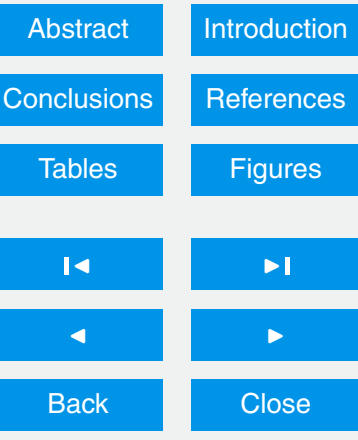

Full Screen / Esc

Printer-friendly Version

Interactive Discussion 
where $\mathrm{d}\left[\mathrm{CH}_{4}\right] / \mathrm{d} t$ is the increase of $\left[\mathrm{CH}_{4}\right]$ and $\tau$ is the mean atmospheric $\mathrm{CH}_{4}$ lifetime. At steady-state, the emission $E$ balances the sink $\left[\mathrm{CH}_{4}\right] / \tau$, since there is no change in the global burden $\left(\mathrm{d}\left[\mathrm{CH}_{4}\right] / \mathrm{d} t=0\right)$. On the other hand, a perturbation of the global budget corresponds to a change, $\Delta E$, in the source strength assuming a constant sink. We 5 calculated $\Delta E$ using a perturbation of the global burden that is equal to $\left[\Delta \mathrm{CH}_{4}\right]$. In other words, we changed the global burden by the amount of the stratospheric correction $\left(\mathrm{d}\left[\mathrm{CH}_{4}\right] / \mathrm{d} t=\left[\Delta \mathrm{CH}_{4}\right] \mathrm{yr}^{-1}\right)$. According to this procedure, we derived flux adjustments for ACTM and for five additional CTMs.

Figure 4 shows zonal contributions of $\Delta E$ aggregated for $30^{\circ}$ latitude bands and 10 averaged over two years. Assuming realistic prior emissions, stratospheric modeltransport errors yield to an overestimation of emissions by $3.2-11.1 \mathrm{Tg} \mathrm{yr}^{-1}$ for the $\mathrm{NH}$ arctic region $\left(60-90^{\circ} \mathrm{N}\right), 5.2-11.7 \mathrm{Tg} \mathrm{yr}^{-1}$ for the $\mathrm{NH}$ midlatitudes $\left(30-60^{\circ} \mathrm{N}\right)$, and 3.413.1 $\mathrm{Tg} \mathrm{yr}^{-1}$ for the $\mathrm{SH}$ midlatitudes $\left(30-60^{\circ} \mathrm{S}\right)$, relative to the tropics. Mean flux errors are $\sim 7 \mathrm{Tgyr}^{-1}$ for each of these three latitudinal bands, and accumulate to $\sim 21 \mathrm{Tg} \mathrm{gr}^{-1}$ 15 on total global scale.

We use two inversion-estimated distributions of emission adjustments (Alexe et al., 2015: S1-NOAA and S1-GOSAT-SRON-PX) to evaluate the significance of these flux errors, see grey and black bars in Fig. 4. One of these inversions uses surface measurements from the Cooperative Air Sampling Network of the National Oceanic and 20 Atmospheric Administration Earth System Research Laboratory (NOAA ESRL) only. The second inversion uses both surface measurements from NOAA ESRL and satellite total column observations from the Thermal And Near infrared Sensor for carbon Observations-Fourier Transform Spectrometer (TANSO-FTS) instrument on board the Greenhouse Gases Observing SATellite (GOSAT). In addition to inversion-estimated flux adjustments we also compared inversion-estimated total emissions with flux errors in order to assess the level of significance for the flux errors: these total emission are small for the arctic region (S1-NOAA: 17.6 $\mathrm{Tg} \mathrm{yr}^{-1}$ ) and for the SH midlatitudes (S1-NOAA: 11.6 $\mathrm{Tgyr}^{-1}$ ) compared to $\mathrm{NH}$ mid-latitude total emissions (S1NOAA: $\left.156.2 \mathrm{Tgyr}^{-1}\right)$.
ACPD

15, 20395-20447, 2015

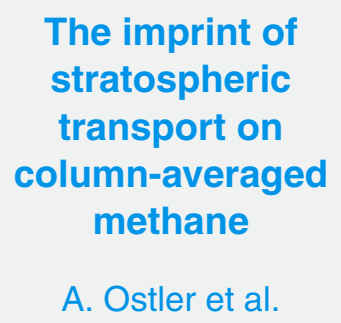

The imprint of stratospheric transport on column-averaged methane

A. Ostler et al.

\section{Title Page}

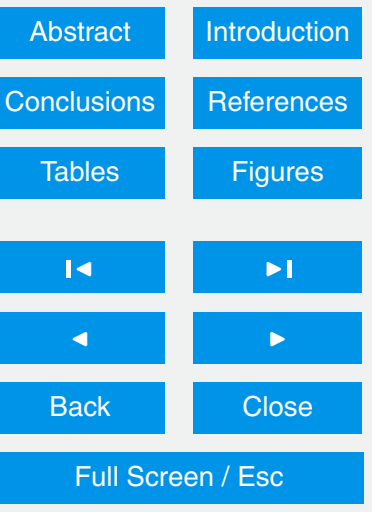

Printer-friendly Version

Interactive Discussion 
For the $\mathrm{NH}$ arctic region, stratospheric model-transport errors are significant, as the average flux error of $\sim 7 \mathrm{Tgyr}^{-1}$ is higher than the inversion-based emission adjustment $\left(2.3 \mathrm{Tg} \mathrm{yr}^{-1}\right)$ and accounts for $\sim 40 \%$ of the inverted total emissions in this region $\left(17.6 \mathrm{Tg} \mathrm{yr}^{-1}\right)$. In the $\mathrm{SH}$ midlatitudes as well, the average flux error of $\sim 7 \mathrm{Tgyr}^{-1}$ is 5 larger than the inversion-based emission adjustment $\left(2.7 \mathrm{Tg} \mathrm{yr}^{-1}\right)$ and corresponds to $\sim 60 \%$ of the inverted total emissions $\left(11.6 \mathrm{Tgyr}^{-1}\right)$. The significance of stratospheric model-transport errors in the $\mathrm{NH}$ midlatitudes is somewhat reduced, since inverted emission adjustments reach up to $27.6 \mathrm{Tg} \mathrm{yr}^{-1}$ and flux errors $\left(\sim 7 \mathrm{Tg} \mathrm{yr}^{-1}\right.$ on average) only account for $\sim 5 \%$ of the inverted total emissions $\left(156.2 \operatorname{Tg~}^{-1}\right)$.

\section{Summary and conclusions}

Based on a parameterization of stratospheric $\mathrm{CH}_{4}$ in terms of mean age of air, this study investigates the sensitivity of $\mathrm{XCH}_{4}$ to stratospheric transport. After constraining stratospheric model transport with $\mathrm{SF}_{6}$-inferred mean age observations, we account for the impact of stratospheric model-transport errors on stratospheric $\mathrm{CH}_{4}$. Our analysis 15 shows that inaccurate modeling of stratospheric transport leads to a poor description of stratospheric $\mathrm{CH}_{4}$ with a systematic overestimation of $\mathrm{CH}_{4}$ mixing ratios by up to $250 \mathrm{ppb}$. ACTM model errors in stratospheric transport and $\mathrm{CH}_{4}$ are increasing towards high latitudes and exhibit a seasonal component. Consequently, the impact of such errors on simulating $\mathrm{XCH}_{4}$ results in biases that are increasing from the tropics $(\sim$ $201 \mathrm{ppb})$ towards the mid- and high-latitude region $(>20 \mathrm{ppb})$. Our correction method produces both an improved overall and seasonal agreement in $\mathrm{XCH}_{4}$ between ACTM and TCCON.

As satellite $\mathrm{XCH}_{4}$ observations combined with CTM simulations are used for inverting $\mathrm{CH}_{4}$ emission fluxes, we provided an estimate for the impact of stratospheric modeltransport errors in terms of emissions. Based on a set of CTMs used for inverse studies, where we found transport errors similar to ACTM, model errors in stratospheric $\mathrm{CH}_{4}$ were converted into flux errors. Global flux errors are $\sim 21 \mathrm{Tg} \mathrm{yr}^{-1}$ on average and

ACPD

15, 20395-20447, 2015

The imprint of stratospheric

transport on

column-averaged

methane

A. Ostler et al.

\section{Title Page}

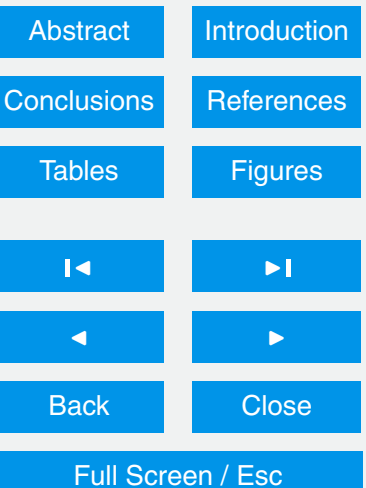

Printer-friendly Version

Interactive Discussion 
correspond to an overestimation of $\mathrm{CH}_{4}$ emissions by $40 \%\left(\sim 7 \mathrm{Tgyr}^{-1}\right)$ in the $\mathrm{NH}$ arctic region, by $\sim 5 \%\left(\sim 7 \mathrm{Tgyr}^{-1}\right)$ in the $\mathrm{NH}$ midlatitudes, and by $\sim 60 \%\left(\sim 7 \mathrm{Tgyr}^{-1}\right)$ in the SH midlatitudes. Assessing these flux errors does not imply that inverted emission estimates are affected by such errors, since inversion studies try to remove systematic 5 error sources, like latitudinal $\mathrm{XCH}_{4}$ biases between model and satellite data, before inverting $\mathrm{CH}_{4}$ fluxes.

Overall, the comparison between ACTM simulations and atmospheric $\mathrm{CH}_{4}$ observations suggests that our stratospheric correction is reasonable, although it does not explicitely account for interannual variability in stratospheric transport and only is based on a small observational dataset of mean age ( $7 \mathrm{SF}_{6}$ profiles at three locations). However, as long as modeled and corrected mean age datasets are consistent in temporal resolution, errors from missing interannual variations in stratospheric transport should cancel each other. We expect, that extending the observational dataset of mean age with additional measurements will contribute to a refined stratospheric correction and, 15 thus, is favorable for future applications. E.g., satellite-inferred age of air data are available for long-term analysis of stratospheric model transport including interannual and seasonal variations (Stiller et al., 2012).

In summary, our results imply three important shortcomings in atmospheric inversions using satellite-derived $\mathrm{XCH}_{4}$. First, satellite-based emission estimates at mid20 and high latitudes can be affected by systematic flux errors of $\sim 7 \mathrm{Tgyr}^{-1}$ on average, if latitudinal bias corrections are not included. These flux errors are in the same order of magnitude as flux differences between satellite-inferred and surface-inferred inversions (Monteil et al., 2013; Alexe et al., 2015). Second, our results indicate that inaccurate stratospheric model transport causes unrealistic emission adjustments by an inversion which tries to consistently interpret constraints on satellite-derived columnaveraged mixing ratios and in situ measurements of surface mixing ratios at the same time (Monteil et al., 2013). Third, residuals between model and satellite $\mathrm{XCH}_{4}$ contain latitude-dependent contributions due to errors in stratospheric model transport superimposed on residuals caused by real atmospheric signals. As long as the stratospheric
ACPD

15, 20395-20447, 2015

\section{The imprint of stratospheric \\ transport on \\ column-averaged methane \\ A. Ostler et al.}

\section{Title Page}

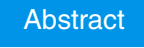

Conclusions

Tables

14

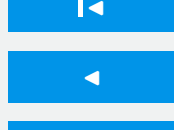

Back
Introduction

References

Figures

$\Delta$
Close

Full Screen / Esc

Printer-friendly Version

Interactive Discussion 
model bias has not been quantified, latitudinal ad hoc bias corrections can obscure real signals inferred from satellite observations.

We expect that these shortcomings in inversions can be alleviated by the correction of stratospheric model transport. In addition, the potential of mean age observations 5 as diagnostic and modality for stratospheric model errors is not limited to $\mathrm{CH}_{4}$, but can also be exploited for other long-lived greenhouse gases like carbon dioxide $\left(\mathrm{CO}_{2}\right)$ or nitrous oxide $\left(\mathrm{N}_{2} \mathrm{O}\right)$. In this context, we conclude that an improved description of the stratospheric column will help to clarify discrepancies between $\mathrm{CO}_{2}$ flux estimates inferred from surface and satellite observations (Basu et al., 2013; Deng et al., 2014; 10 Chevallier et al., 2014). It also is likely, that improved stratospheric modeling can give new insights into an ongoing debate about the inversion-estimated European uptake of $\mathrm{CO}_{2}$ (Reuter et al., 2014; Feng et al., 2015).

Our findings suggest that an accurate representation of the stratosphere is essential in order to determine source/sink information from the inversion of satellite total column 15 observations. An alternative to separate tropospheric and stratospheric contributions from $\mathrm{XCH}_{4}$ has been presented for ground-based observations (Washenfelder et al., 2003), but is not applicable for satellite observations at the moment without additional use of a CTM. It is obvious, that the best solution to the model bias in stratospheric methane is to improve the representation of the stratosphere. This is a reasonable goal, as a realistic simulation of stratospheric transport has already been achieved by models focused on stratospheric tracers (Strahan et al., 2011). However, for atmospheric inversions, the age correction proposed here can act as a solution at an intermediate stage between currently used ad hoc bias corrections and accurate modeling of stratospheric $\mathrm{CH}_{4}$ in the future.

Apart from that, the stratospheric correction via mean age can be beneficial for satellite or ground-based retrieval methods; i.e. improved stratospheric a priori information from CTMs will result in enhanced retrieval accuracy. Finally, this study again reveals the synergistic potential of combining CTMs with high-precision measurements.
ACPD

15, 20395-20447, 2015

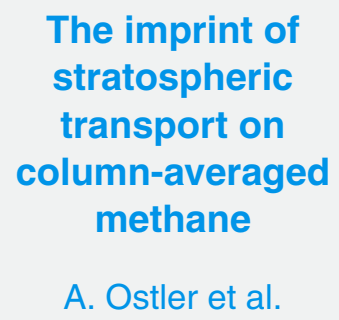

The imprint of stratospheric transport on column-averaged methane

A. Ostler et al.

\section{Title Page}

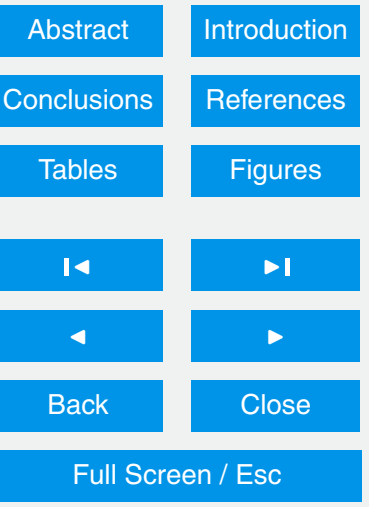

Printer-friendly Version

Interactive Discussion 


\section{Appendix A: Details of the stratospheric correction}

As explained in Sect. 4.2, the correction of stratospheric $\mathrm{CH}_{4}$ mixing ratios has three contributions: chemical loss, tropospheric growth, and interaction of chemistry and growth. These individual contributions are illustrated in Fig. A1, using original and

5 corrected ACTM model profiles of $\mathrm{CH}_{4}$ mixing ratios extracted for the TCCON site Garmisch. It is obvious that the predominant part of the correction for a chemicallyactive trace gas such as $\mathrm{CH}_{4}$ originates from the chemical loss term with $\mathrm{CH}_{4}$ adjustments up to $\sim 150 \mathrm{ppb}$ in the lower stratosphere. The contribution caused by tropospheric growth is typically lower than $20 \mathrm{ppb}$ throughout the whole stratosphere. In contrast to the contributions from chemical loss and tropospheric growth, the amount of the mixed chemistry-growth term is monotonically increasing from $\sim 20 \mathrm{ppb}$ in the lower stratosphere up to $\sim 90 \mathrm{ppb}$ in the upper stratosphere.

The correction of ACTM stratospheric $\mathrm{CH}_{4}$ is not constant with time, but shows a seasonal component due to seasonal varying differences between simulated and corrected 15 age. Latitude-height distributions of age and $\mathrm{CH}_{4}$ reveal that the correction effect has a maximum in winter-time and a minimum in summer (Fig. A2).

\section{Appendix B: Supplement figures}

Impact of stratospheric model-transport errors on mean seasonal variations of $\mathrm{XCH}_{4}$ (see Fig. B1).

\section{Appendix C: Comparison of stratospheric $\mathrm{CH}_{4}$ between ACTM and satellite data}

For the validation of the stratospheric model correction we also used two stratospheric $\mathrm{CH}_{4}$ climatologies which have been inferred from observations of the Halogen Occultation Experiment (HALOE) on board the Upper Atmosphere Research Satellite (UARS) and of the Atmospheric Chemistry Experiment-Fourier Transform Spectrometer (ACE-
ACPD

15, 20395-20447, 2015

The imprint of stratospheric

transport on

column-averaged

methane

A. Ostler et al.

\section{Title Page}

Abstract

Conclusions

Tables

14 4 4

Back

Full Screen / Esc

Printer-friendly Version

Interactive Discussion

Close

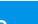


FTS) aboard the Canadian Science Satellite (SciSat). Both satellite instruments utilize solar occultation geometry to obtain vertical profiles of several trace gases including $\mathrm{CH}_{4}$. The HALOE climatology is derived from measurements covering a period of 11 years (1991-2002), the ACE-FTS climatology is based on observations performed 5 between 2004 and 2009. Both climatologies are provided as zonal monthly mean distributions (Jones et al., 2012; Grooß and Russell, 2005). Comparisons between ACEFTS and correlative HALOE profiles have revealed that ACE-FTS profiles are biased positive ( $~ 5 \%$ up to $35 \mathrm{~km} ; \sim 15 \%$ up to $60 \mathrm{~km}$ ) with respect to HALOE (de Mazière et al., 2008). A comparison between a vertical $\mathrm{CH}_{4}$ profile from ACT-FTS and from 10 balloon-borne measurements showed biases that are smaller than $\pm 10 \%$ between 15 and $24 \mathrm{~km}$ (de Mazière et al., 2008). The agreement of HALOE profiles with correlative measurements was found to be better than $15 \%$ (Park et al., 1996).

For comparison with satellite-inferred climatologies we used zonally-averaged monthly mean distributions of ACTM, and ACTMac, respectively. Modeled $\mathrm{CH}_{4}$ distri15 butions from the years 2008 and 2009 were averaged for each month and subsequently compared with the climatological monthly mean distributions from HALOE and ACEFTS. As the HALOE climatology is representative for the $1990 \mathrm{~s}$, we have to account for the tropospheric growth. I.e. the modeled $\mathrm{CH}_{4}$ distributions are adjusted by an offset corresponding to the increase in global $\mathrm{CH}_{4}$ between the ACTM time period (2008, 2009) and the HALOE climatology period. As the period between 1999 and 2006 does not show significant growth, we account for 6 years of tropospheric growth with a rate of $7 \mathrm{ppbyr}^{-1}$ (42 ppb in total; see ref. 40 for tropospheric growth rate). Due to the small time lag between model and ACE-FTS climatology, the impact of tropospheric growth on model-satellite comparison can be neglected.

25 Zonal differences between model and satellite climatology were calculated as a function of altitude and month. Subsequently, these zonal differences were used to derive the mean difference (bias) and the residual standard deviation (RSD). Furthermore, we calculated the standard deviation of the individual $\mathrm{CH}_{4}$ distributions (ACTM, ACTMac, and satellite) in order to use it as a proxy for modeled and observed atmospheric

\section{ACPD}

15, 20395-20447, 2015

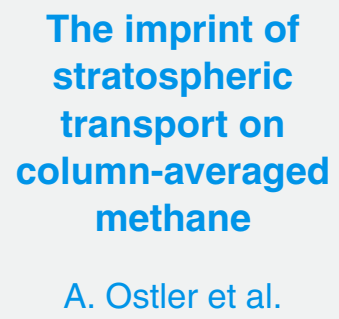

The imprint of stratospheric transport on column-averaged methane

A. Ostler et al.

\section{Title Page}

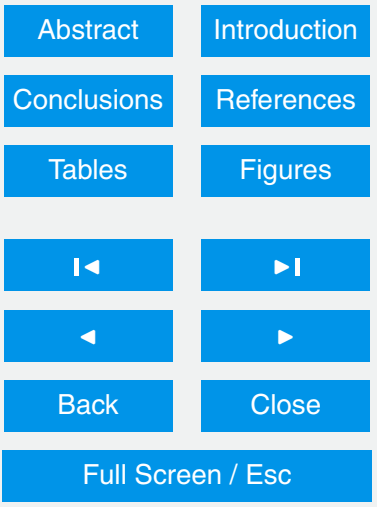

Printer-friendly Version

Interactive Discussion 
variability. We find that the average agreement between model and satellite zonal $\mathrm{CH}_{4}$ distributions is improved throughout the entire stratosphere at all latitudes for ACTMac compared to ACTM. E.g., the global bias of the model relative to ACE-FTS is reduced from $\sim 10 \%$ to $\sim 5 \%$ in the lower stratosphere $(50-200 \mathrm{hPa})$ when using ACTMac in-

5 stead of ACTM (Fig. C1). Similar results were found for the model bias with respect to HALOE (Fig. C2). Furthermore, the variability of corrected model distributions is similar to the variability of satellite climatologies (Figs. C1e, C1f, C2e, and C2f), indicating that the corrected model provides a better description of stratospheric $\mathrm{CH}_{4}$ variability.

\section{Appendix D}

10 Age distributions from TransCom CTMs were compared with corrected age distributions from ACTM in order to detect errors in stratospheric model transport. Figure D1 shows age differences as latitude-height distributions averaged for all months of the years 2006 and 2007. It is obvious that all CTMs are affected by a similar latitudedependent transport error given the similar patterns of age errors. The modeled $\mathrm{CH}_{4}$ 15 distributions of the TransCom CTMs were corrected with respect to age in order to account for the stratospheric model-transport error. Figure D2 shows differences between original and corrected $\mathrm{CH}_{4}$ distributions.

Acknowledgements. We thank H. P. Schmid (IMK-IFU) for his continual interest in this work. Our work has been performed as part of the ESA GHG-cci project via subcontract with the University of Bremen. In addition we acknowledge funding by the EC within the INGOS project. We thank the Deutsche Forschungsgemeinschaft and Open Access Publishing Fund of the Karlsruhe Institute of Technology for support. A part of work at JAXA was supported by the Environment Research and Technology Development Fund (A-1102) of the Ministry of the Environment, Japan. From 2004 to 2011 the Lauder TCCON program was funded by the New 25 Zealand Foundation of Research Science and Technology contracts CO1X0204, CO1X0703 and CO1X0406. Since 2011 the program has been funded by NIWA's Atmosphere Research Program 3 (2011/13 Statement of Corporate Intent).

\section{The imprint of stratospheric transport on column-averaged} methane

A. Ostler et al.

\section{Title Page}

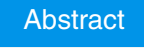

Conclusions

Tables

14

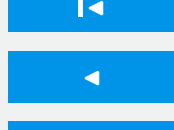

Back
Introduction

References

Figures

$\Delta$

\section{Close}

Full Screen / Esc

Printer-friendly Version

Interactive Discussion 


\section{ACPD}

15, 20395-20447, 2015

\section{References}

Alexe, M., Bergamaschi, P., Segers, A., Detmers, R., Butz, A., Hasekamp, O., Guerlet, S., Parker, R., Boesch, H., Frankenberg, C., Scheepmaker, R. A., Dlugokencky, E., Sweeney, C., Wofsy, S. C., and Kort, E. A.: Inverse modelling of $\mathrm{CH}_{4}$ emissions for 2010-2011 using different satellite retrieval products from GOSAT and SCIAMACHY, Atmos. Chem. Phys., 15, 113-133, doi:10.5194/acp-15-113-2015, 2015.

Basu, S., Guerlet, S., Butz, A., Houweling, S., Hasekamp, O., Aben, I., Krummel, P., Steele, P., 10 Langenfelds, R., Torn, M., Biraud, S., Stephens, B., Andrews, A., and Worthy, D.: Global $\mathrm{CO}_{2}$ fluxes estimated from GOSAT retrievals of total column $\mathrm{CO}_{2}$, Atmos. Chem. Phys., 13, 8695-8717, doi:10.5194/acp-13-8695-2013, 2013.

Bergamaschi, P., Houweling, S., Segers, A., Krol, M., Frankenberg, C., Scheepmaker, R. A., Dlugokencky, E., Wofsy, S. C., Kort, E. A., Sweeney, C., Schuck, T., Brenninkmeijer, C., , $\mathrm{H}$., Beck, $\mathrm{V}$, and Gerbig, $\mathrm{C}$ : Atmospheric $\mathrm{CH}_{4}$ in the first decade of the 21st century: inverse modeling analysis using SCIAMACHY satellite retrievals and NOAA surface measurements, J. Geophys. Res., 118, 7350-7369, doi:10.1002/jgrd.50480, 2013.

Blumenstock, T., Hase, F., Schneider, M., García, O. E., and Sepúlveda, E.: TCCON data from Izana, Tenerife, Spain, release GGG2014R0, TCCON data archive, hosted by the Carbon Dioxide Information Analysis Center, Oak Ridge National Laboratory, Oak Ridge, Tennessee, USA, doi:10.14291/tccon.ggg2014.izana01.R0/1149295, 2014.

Chevallier, F., Palmer, P. I., Feng, L., Boesch, H., O'Dell, C., W., and Bousquet, P.: Toward robust and consistent regional $\mathrm{CO}_{2}$ flux estimates from in situ and spaceborne measurements of atmospheric $\mathrm{CO}_{2}$, Geophys. Res. Lett., 41, 1065-1070, doi:10.1002/2013GL058772, 2014.

Chipperfield, M. P.: New version of the TOMCAT/SLIMCAT offline chemical transport model: intercomparison of stratospheric tracer experiments, Q. J. Roy. Meteor. Soc., 132, 11791203, doi:10.1256/qj.05.51, 2006.

Cressot, C., Chevallier, F., Bousquet, P., Crevoisier, C., Dlugokencky, E. J., Fortems-Cheiney, A., Frankenberg, C., Parker, R., Pison, I., Scheepmaker, R. A., Montzka, S. A., Krummel, P. B., Steele, L. P., and Langenfelds, R. L.: On the consistency between global and regional

\section{The imprint of stratospheric transport on \\ column-averaged methane \\ A. Ostler et al.}

\section{Title Page}

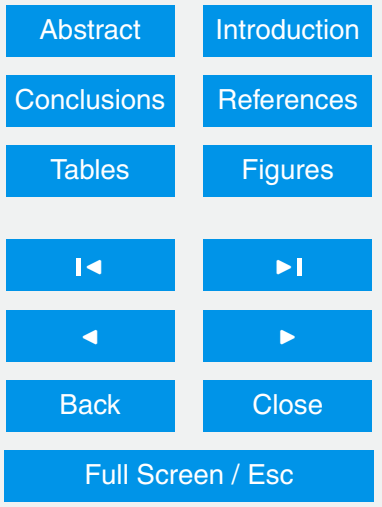

Printer-friendly Version

Interactive Discussion 
methane emissions inferred from SCIAMACHY, TANSO-FTS, IASI and surface measurements, Atmos. Chem. Phys., 14, 577-592, doi:10.5194/acp-14-577-2014, 2014.

De Mazière, M., Vigouroux, C., Bernath, P. F., Baron, P., Blumenstock, T., Boone, C., Brogniez, C., Catoire, V., Coffey, M., Duchatelet, P., Griffith, D., Hannigan, J., Kasai, Y., Kramer, I.,

5 Jones, N., Mahieu, E., Manney, G. L., Piccolo, C., Randall, C., Robert, C., Senten, C., Strong, K., Taylor, J., Tétard, C., Walker, K. A., and Wood, S.: Validation of ACE-FTS v2.2 methane profiles from the upper troposphere to the lower mesosphere, Atmos. Chem. Phys., 8, 2421-2435, doi:10.5194/acp-8-2421-2008, 2008.

De Maziere, M., Desmet, F., Hermans, C., Scolas, F., Kumps, N., Metzger, J.-M., Duflot, V., and Cammas, J.-P.: TCCON data from Reunion Island (La Reunion), France, Release GGG2014R0, TCCON data archive, hosted by the Carbon Dioxide Information Analysis Center, Oak Ridge National Laboratory, Oak Ridge, Tennessee, USA, doi:10.14291/tccon.ggg2014.reunion01.R0/1149288, 2014.

Deng, F., Jones, D. B. A., Henze, D. K., Bousserez, N., Bowman, K. W., Fisher, J. B., Nassar, R., O'Dell, C., Wunch, D., Wennberg, P. O., Kort, E. A., Wofsy, S. C., Blumenstock, T., Deutscher, N. M., Griffith, D. W. T., Hase, F., Heikkinen, P., Sherlock, V., Strong, K., Sussmann, R., and Warneke, T.: Inferring regional sources and sinks of atmospheric $\mathrm{CO}_{2}$ from GOSAT $\mathrm{XCO}_{2}$ data, Atmos. Chem. Phys., 14, 3703-3727, doi:10.5194/acp-14-3703-2014, 2014.

20

Deutscher, N., Notholt, J., Messerschmidt, J., Weinzierl, C., Warneke, T., Petri, C., Gruppe, P., and Katrynski, K.: TCCON data from Bialystok, Poland, Release GGG2014R0, TCCON data archive, hosted by the Carbon Dioxide Information Analysis Center, Oak Ridge National Laboratory, Oak Ridge, Tennessee, USA, doi:10.14291/tccon.ggg2014.bialystok01.R0/1149277, 2014

Dlugokencky, E. J., Masarie, K. A., Lang, P. M., and Tans, P. P.: Continuing decline in the growth rate of the atmospheric methane burden, Nature, 393, 447-450, 1998.

Dlugokencky, E. J., Bruhwiler, L., White, J. W. C., Emmons, L. K., Novelli, P. C., Montzka, S. A., Masarie, K. A., Lang, P. M., Crotwell, A. M., Miller, J. B., and Gatti, L. V.: Observational constraints on recent increases in the atmospheric $\mathrm{CH}_{4}$ burden, Geophys. Res. Lett., 36, $30 \quad$ L18803, doi:10.1029/2009GL039780, 2009.

Engel, A., Mobius, T., Bonisch, H., Schmidt, U., Heinz, R., Levin, I., Atlas, E., Aoki, S., Nakazawa, T., Sugawara, S., Moore, F., Hurst, D., Elkins, J., Schauffler, S., Andrews, A., and

\section{ACPD}

15, 20395-20447, 2015

\section{The imprint of stratospheric transport on \\ column-averaged methane \\ A. Ostler et al.}

\section{Title Page}

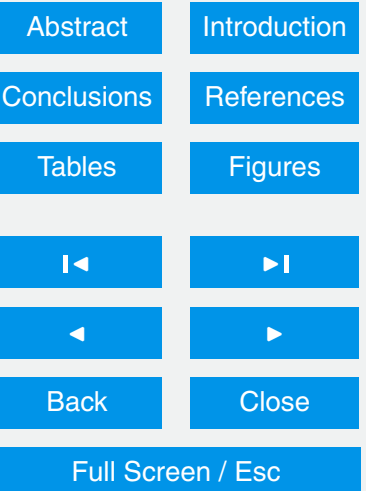

Printer-friendly Version

Interactive Discussion 
Boering, K.: Age of stratospheric air unchanged within uncertainties over the past 30 years, Nat. Geosci., 2, 28-31, 2009.

Feng, L., Palmer, P. I., Parker, R. J., Deutscher, N. M., Feist, D. G., Kivi, R., Morino, I., and Sussmann, R.: Elevated uptake of $\mathrm{CO}_{2}$ over Europe inferred from $\mathrm{GOSAT} \mathrm{XCO}_{2}$ retrievals: 5 a real phenomenon or an artefact of the analysis?, Atmos. Chem. Phys. Discuss., 15, 19892011, doi:10.5194/acpd-15-1989-2015, 2015.

Fraser, A., Chan Miller, C., Palmer, P. I., Deutscher, N. M., Jones, N. B., and Griffith, D. W. T.: The Australian methane budget: interpreting surface and train-borne measurements using a chemistry transport model, J. Geophys. Res., 116, D20306, doi:10.1029/2011JD015964, 102011.

Fraser, A., Palmer, P. I., Feng, L., Boesch, H., Cogan, A., Parker, R., Dlugokencky, E. J., Fraser, P. J., Krummel, P. B., Langenfelds, R. L., O'Doherty, S., Prinn, R. G., Steele, L. P., van der Schoot, M., and Weiss, R. F.: Estimating regional methane surface fluxes: the relative importance of surface and GOSAT mole fraction measurements, Atmos. Chem. Phys., 13, 5697-5713, doi:10.5194/acp-13-5697-2013, 2013.

Fraser, A., Palmer, P. I., Feng, L., Bösch, H., Parker, R., Dlugokencky, E. J., Krummel, P. B., and Langenfelds, R. L.: Estimating regional fluxes of $\mathrm{CO}_{2}$ and $\mathrm{CH}_{4}$ using space-borne observations of $\mathrm{XCH}_{4}: \mathrm{XCO}_{2}$, Atmos. Chem. Phys., 14, 12883-12895, doi:10.5194/acp-14-128832014, 2014.

20 Fung, I., John, J., Lerner, J., Matthews, E., Prather, M., Steele, L. P., and Fraser, P. J.: Threedimensional model synthesis of the global methane cycle, J. Geophys. Res., 96, 1303313065, doi:10.1029/91JD01247, 1991.

Geibel, M. C., Messerschmidt, J., Gerbig, C., Blumenstock, T., Chen, H., Hase, F., Kolle, O., Lavrič, J. V., Notholt, J., Palm, M., Rettinger, M., Schmidt, M., Sussmann, R., Warneke, T., and Feist, D. G.: Calibration of column-averaged $\mathrm{CH}_{4}$ over European TCCON FTS sites with airborne in-situ measurements, Atmos. Chem. Phys., 12, 8763-8775, doi:10.5194/acp-128763-2012, 2012.

Grooß, J.-U. and Russell III, James M.: Technical note: a stratospheric climatology for $\mathrm{O}_{3}, \mathrm{H}_{2} \mathrm{O}$, $\mathrm{CH}_{4}, \mathrm{NO}_{x}, \mathrm{HCl}$ and $\mathrm{HF}$ derived from HALOE measurements, Atmos. Chem. Phys., 5, 27972807, doi:10.5194/acp-5-2797-2005, 2005.

Griffith, D. W. T., Deutscher, N., Velazco, V. A., Wennberg, P. O., Yavin, Y., Keppel Aleks, G., Washenfelder, R., Toon, G. C., Blavier, J.-F., Murphy, C., Jones, N., Kettlewell, G., Connor, B., Macatangay, R., Roehl, C., Ryczek, M., Glowacki, J., Culgan, T., and Bryant, G.: TCCON data

\section{ACPD}

15, 20395-20447, 2015

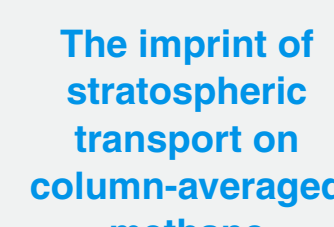

methane

A. Ostler et al.

\section{Title Page}

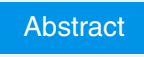

Conclusions

Tables

Introduction References

Figures

14

4

Back

Close

Full Screen / Esc

Printer-friendly Version

Interactive Discussion 
from Darwin, Australia, Release GGG2014R0, TCCON data archive, hosted by the Carbon Dioxide Information Analysis Center, Oak Ridge National Laboratory, Oak Ridge, Tennessee, USA, doi:10.14291/tccon.ggg2014.darwin01.R0/1149290, 2014a.

Griffith, D. W. T., Velazco, V. A., Deutscher, N., Murphy, C., Jones, N., Wilson, S., Macatangay, R., Kettlewell, G., Buchholz, R. R., and Riggenbach, M.: TCCON data from Wollongong, Australia, Release GGG2014R0, TCCON data archive, hosted by the Carbon Dioxide Information Analysis Center, Oak Ridge National Laboratory, Oak Ridge, Tennessee, USA doi:10.14291/tccon.ggg2014.wollongong01.R0/1149291, 2014b.

Hall, T. M. and Plumb, R. A.: Age as a diagnostic of stratospheric transport, J. Geophys. Res., 99, 1059-1070, 1994.

Harnisch, J., Borchers, R., Fabian, P., and Maiss, M.: Tropospheric trends for $\mathrm{CF}_{4}$ and $\mathrm{C}_{2} \mathrm{~F}_{6}$ since 1982 derived from SF $_{6}$ dated stratospheric air, Geophys. Res. Lett., 23, 1099-1102, 1996.

Hase, F., Blumenstock, T., Dohe, S., Groß, J., and Kiel, M.: TCCON data from Karlsruhe, Germany, Release GGG2014R0, TCCON data archive, hosted by the Carbon Dioxide Information Analysis Center, Oak Ridge National Laboratory, Oak Ridge, Tennessee, USA, doi:10.14291/tccon.ggg2014.karlsruhe01.R0/1149270, 2014.

Houweling, S., Krol, M., Bergamaschi, P., Frankenberg, C., Dlugokencky, E. J., Morino, I., Notholt, J., Sherlock, V., Wunch, D., Beck, V., Gerbig, C., Chen, H., Kort, E. A., Röckmann, T., and Aben, I.: A multi-year methane inversion using SCIAMACHY, accounting for systematic errors using TCCON measurements, Atmos. Chem. Phys., 14, 3991-4012, doi:10.5194/acp14-3991-2014, 2014.

Jones, A., Walker, K. A., Jin, J. J., Taylor, J. R., Boone, C. D., Bernath, P. F., Brohede, S., Manney, G. L., McLeod, S., Hughes, R., and Daffer, W. H.: Technical Note: A trace gas climatology derived from the atmospheric chemistry experiment fourier transform spectrometer (ACE-FTS) data set, Atmos. Chem. Phys., 12, 5207-5220, doi:10.5194/acp-12-5207-2012, 2012.

Kawakami, S., Ohyama, H., Arai, K., Okumura, H., Taura, C., Fukamachi, T., and Sakashita, M.; TCCON data from Saga, Japan, Release GGG2014R0, TCCON data archive, hosted by the
Carbon Dioxide Information Analysis Center, Oak Ridge National Laboratory, Oak Ridge, Tennessee, USA, doi:10.14291/tccon.ggg2014.saga01.R0/1149283, 2014.

Kirschke, S., Bousquet, P., Ciais, P., Saunois, M., Canadell, J. G., Dlugokencky, E. J., Bergamaschi, P., Bergmann, D., Blake, D. R., Bruhwiler, L., Cameron-Smith, P., Castaldi, S.,
ACPD

15, 20395-20447, 2015

\section{The imprint of \\ stratospheric \\ transport on \\ column-averaged \\ methane \\ A. Ostler et al.}

\section{Title Page}

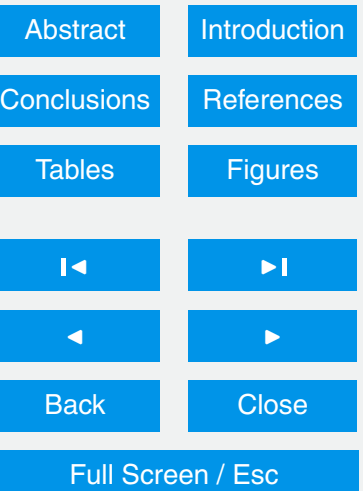

Printer-friendly Version

Interactive Discussion 
Chevallier, F., Feng, L., Fraser, A., Heimann, M., Hodson, E. L., Houweling, S., Josse, B., Fraser, P. J., Krummel, P. B., Lamarque, J. F., Langenfelds, R. L., Le Quere, C., Naik, V., O'Doherty, S., Palmer, P. I., Pison, I., Plummer, D., Poulter, B., Prinn, R. G., Rigby, M., Ringeval, B., Santini, M., Schmidt, M., Shindell, D. T., Simpson, I., Spahni, R., Steele, L. P., Strode, S. A., Sudo, K., Szopa, S., van der Werf, G. R., Voulgarakis, A., van Weele, M., Weiss, R. F., Williams, J. E., and Zeng, G.: Three decades of global methane sources and sinks, Nat. Geosci., 6, 813-823, doi:10.1038/ngeo1955, 2013.

Kivi, R., Heikkinen, P., and Kyro, E.: TCCON data from Sodankyla, Finland, Release GGG2014R0, TCCON data archive, hosted by the Carbon Dioxide Information Analysis Center, Oak Ridge National Laboratory, Oak Ridge, Tennessee, USA, doi:10.14291/tccon.ggg2014.sodankyla01.R0/1149280, 2014.

Krol, M., Houweling, S., Bregman, B., van den Broek, M., Segers, A., van Velthoven, P., Peters, W., Dentener, F., and Bergamaschi, P.: The two-way nested global chemistrytransport zoom model TM5: algorithm and applications, Atmos. Chem. Phys., 5, 417-432, doi:10.5194/acp-5-417-2005, 2005.

Mahieu, E., Chipperfield, M. P., Notholt, J., Reddmann, T., Anderson, J., Bernath, P. F., Blumenstock, T., Coffey, M. T., Dhomse, S. S., Feng, W., Franco, B., Froidevaux, L., Griffith, D. W. T., Hannigan, J. W., Hase, F., Hossaini, R., Jones, N. B., Morino, I., Murata, I., Nakajima, H., Palm, M., Paton-Walsh, C., Russell III, J. M., Schneider, M., Servais, C., Smale, D., and Walker, K. A.: Recent Northern Hemisphere stratospheric $\mathrm{HCl}$ increase due to atmospheric circulation changes, Nature, 515, 104-107, doi:10.1038/nature13857, 2014.

Messerschmidt, J., Geibel, M. C., Blumenstock, T., Chen, H., Deutscher, N. M., Engel, A., Feist, D. G., Gerbig, C., Gisi, M., Hase, F., Katrynski, K., Kolle, O., Lavrič, J. V., Notholt, J., Palm, M., Ramonet, M., Rettinger, M., Schmidt, M., Sussmann, R., Toon, G. C., Truong, F., Warneke, T., Wennberg, P. O., Wunch, D., and Xueref-Remy, I.: Calibration of TCCON column-averaged $\mathrm{CO}_{2}$ : the first aircraft campaign over European TCCON sites, Atmos. Chem. Phys., 11, 10765-10777, doi:10.5194/acp-11-10765-2011, 2011.

Miyamoto, Y., Inoue, M., Morino, I., Uchino, O., Yokota, T., Machida, T., Sawa, Y., Matsueda, H., Sweeney, C., Tans, P. P., Andrews, A. E., and Patra, P. K.: Atmospheric column-averaged mole fractions of carbon dioxide at 53 aircraft measurement sites, Atmos. Chem. Phys., 13, 5265-5275, doi:10.5194/acp-13-5265-2013, 2013.

Monteil, G., Houweling, S., Butz, A., Guerlet, S., Schepers, D., Hasekamp, O., Frankenberg, C., Scheepmaker, R., Aben, I., and Röckmann, T.: Comparison of $\mathrm{CH}_{4}$ inversions based on 15
ACPD

15, 20395-20447, 2015

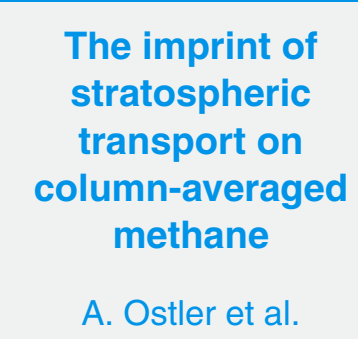

Title Page

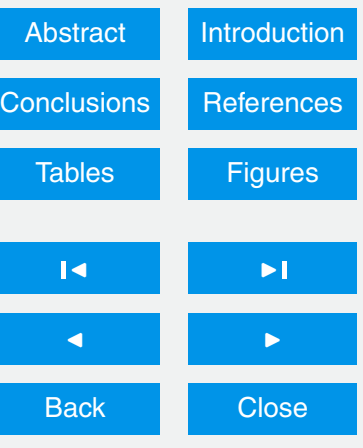

Full Screen / Esc

Printer-friendly Version

Interactive Discussion 
months of GOSAT and SCIAMACHY observations, J. Geophys. Res.-Atmos., 118, 1180711823, doi:10.1002/2013JD019760, 2013.

Montzka, S. A., Krol, M., Dlugokencky, E., Hall, B., Jockel, P., and Lelieveld, J.: Small interannual variability of global atmospheric hydroxyl, Science, 331, 67-69, doi:10.1126/science.1197640, 2011.

Nisbet, E. G., Dlugokencky, E. J., and Bousquet, P.: Methane on the rise - again, Science, 343, 493-495, doi:10.1126/science.1247828, 2014.

Olivier, J. G. J. and Berdowski, J. J. M.: Global emissions sources and sinks, in: The Climate System, edited by: Berdowski, J., Guicherit, R., and Heij, B. J., A. A. Balkema Publishers/Swets and Zeitlinger Pub., Lisse, the Netherlands, 33-78, ISBN 9058092550, 2001.

Patra, P., Lal, S., Subbaraya, B., Jackman, C. H., and Rajaratnam, P.: Observed vertical profile of sulfur hexafluoride $\left(\mathrm{SF}_{6}\right)$ and its atmospheric applications, J. Geophys. Res., 102, 88558859, 1997.

Patra, P. K., Takigawa, M., Dutton, G. S., Uhse, K., Ishijima, K., Lintner, B. R., Miyazaki, K., and Elkins, J. W.: Transport mechanisms for synoptic, seasonal and interannual $\mathrm{SF}_{6}$ variations and "age" of air in troposphere, Atmos. Chem. Phys., 9, 1209-1225, doi:10.5194/acp-9-12092009, 2009a.

Patra, P. K., Takigawa, M., Ishijima, K., Choi, B.-C., Cunnold, D., Dlugokencky, E. J., Fraser, P., Gomez-Pelaez, A. J., Goo, T.-Y., Kim, J.-S., Krummel, P., Langenfelds, R., Meinhardt, F., Mukai, H., O'Doherty, S., Prinn, R. G., Simmonds, P., Steele, P., Tohjima, Y., Tsuboi, K., Unse, K., Weiss, R., Worthy, D., and Nakazawa, T.: Growth rate, seasonal, synoptic, diurnal variations and budget of methane in lower atmosphere, J. Meteorol. Soc. Jpn., 87, 635-663, 2009b.

Patra, P. K., Houweling, S., Krol, M., Bousquet, P., Belikov, D., Bergmann, D., Bian, H., 25 Cameron-Smith, P., Chipperfield, M. P., Corbin, K., Fortems-Cheiney, A., Fraser, A., Gloor, E., Hess, P., Ito, A., Kawa, S. R., Law, R. M., Loh, Z., Maksyutov, S., Meng, L., Palmer, P. I., Prinn, R. G., Rigby, M., Saito, R., and Wilson, C.: TransCom model simulations of $\mathrm{CH}_{4}$ and related species: linking transport, surface flux and chemical loss with $\mathrm{CH}_{4}$ variability in the troposphere and lower stratosphere, Atmos. Chem. Phys., 11, 12813-12837, doi:10.5194/acp11-12813-2011, 2011.

Patra, P. K., Krol, M. C., Montzka, S. A., Arnold, T., Atlas, E. L., Lintner, B. R., Stephens, B. B., Xiang, B., Elkins, J. W., Fraser, P. J., Ghosh, A., Hintsa, E. J., Hurst, D. F., Ishijima, K., Krummel, P. B., Miller, B. R., Miyazaki, K., Moore, F. L., Mühle, J., O’Doherty, S., Prinn, R. G.,
ACPD

15, 20395-20447, 2015

\section{The imprint of \\ stratospheric \\ transport on \\ column-averaged \\ methane \\ A. Ostler et al.}

\section{Title Page}

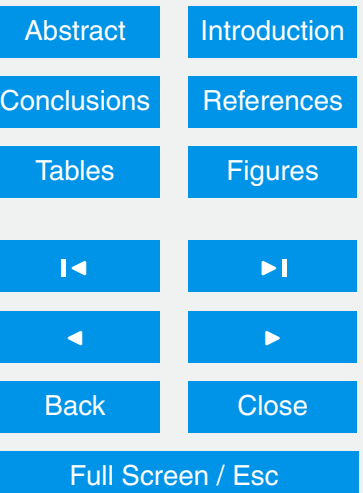

Printer-friendly Version

Interactive Discussion 
Steele, L. P., Takigawa, M., Wang, H. J., Weiss, R. F., Wofsy, S. C., and Young, D.: Observational evidence for interhemispheric hydroxyl parity, Nature, 513, 219-223, 2014.

Park, J. H., Russell, J. M., Gordley, L. L., Drayson, S. R., Benner, D. C., McInerney, J. M., Gunson, M. R., Toon, G. C., Sen, B., Blavier, J. F., Webster, C. R., Zipf, E. C., Erdman, P., 5 Schmidt, U., and Schiller, C.: Validation of halogen occultation experiment $\mathrm{CH}_{4}$ measurements from the UARS, J. Geophys. Res., 101, 10183-10203, 1996.

Pickett-Heaps, C. A., Jacob, D. J., Wecht, K. J., Kort, E. A., Wofsy, S. C., Diskin, G. S., Worthy, D. E. J., Kaplan, J. O., Bey, I., and Drevet, J.: Magnitude and seasonality of wetland methane emissions from the Hudson Bay Lowlands (Canada), Atmos. Chem. Phys., 11, 3773-3779, doi:10.5194/acp-11-3773-2011, 2011.

Reuter, M., Buchwitz, M., Hilker, M., Heymann, J., Schneising, O., Pillai, D., Bovensmann, H., Burrows, J. P., Bösch, H., Parker, R., Butz, A., Hasekamp, O., O'Dell, C. W., Yoshida, Y., Gerbig, C., Nehrkorn, T., Deutscher, N. M., Warneke, T., Notholt, J., Hase, F., Kivi, R., Sussmann, R., Machida, T., Matsueda, H., and Sawa, Y.: Satellite-inferred European carbon sink larger than expected, Atmos. Chem. Phys., 14, 13739-13753, doi:10.5194/acp-14-137392014, 2014.

Saito, R., Patra, P., Sweeney, C., Machida, T., Krol, M., Houweling, S., Bousquet, P., Agustipanareda, A., Belikov, D., Bergmann, D., Bian, H., Cameron-Smith, P., Chipperfield, M., Fortems-Cheney, A., Fraser, A., Gatti, M., Gloor, E., Hess, P., Kawa, S., Law, R., Locatelli, R., Loe, Z., Maksyutov, S., Meng, L., Miller, J., Palmer, P., Prinn, R., Rigby, M., and Wilson, C.: TransCom model simulations of methane: comparison of vertical profiles with in situ aircraft measurements, J. Geophys. Res., 118, 3891-3904, 2013.

Sander, S. P., Golden, D. M., Kurylo, M. J., Moortgat, G. K., Keller-Rudek, H., Wine, P. H., Ravishankara, A. R., Kolb, C. E., Molina, M. J., Finlayson-Pitts, B. J., Huie, R. E., and Orkin, V. L.: Chemical Kinetics and Photochemical Data for Use in Atmospheric Studies, Evaluation Number 15, JPL Publication 06-2, Jet Propulsion Laboratory, California Institute of Technology, Pasadena, CA., 2006.

Sherlock, V., Connor, B., Robinson, J., Shiona, H., Smale, D., and Pollard, D.: TCCON data from Lauder, New Zealand, 120HR, Release GGG2014R0, TCCON data archive, hosted by Tennessee, USA, doi:10.14291/tccon.ggg2014.lauder01.R0/1149293, 2014a.

Sherlock, V., Connor, B., Robinson, J., Shiona, H., Smale, D., and Pollard, D.: TCCON data from Lauder, New Zealand, 125HR, Release GGG2014R0, TCCON data archive, hosted by

ACPD

15, 20395-20447, 2015

\section{The imprint of stratospheric transport on column-averaged methane \\ A. Ostler et al.}

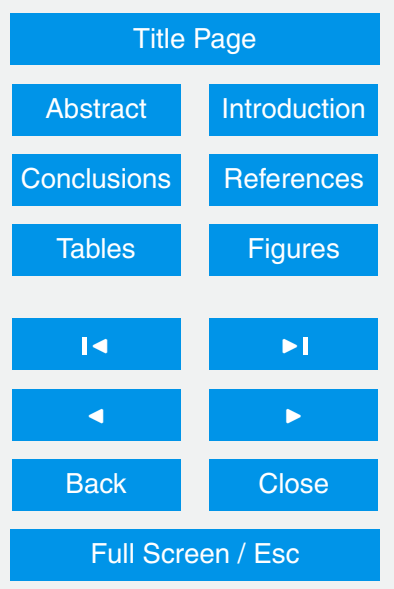

Printer-friendly Version

Interactive Discussion 
the Carbon Dioxide Information Analysis Center, Oak Ridge National Laboratory, Oak Ridge, Tennessee, USA, doi:10.14291/tccon.ggg2014.lauder02.R0/1149298, 2014b.

Spivakovsky, C., Logan, J. A., Montzka, S. A., Balkanski, Y. J., Foreman-Fowler, M., Jones, D. B. A., Horowitz, L. W., Fusco, A. C., Brenninkmeijer, C. A. M., Prather, M. J.,

$5 \quad$ Wofsy, S. C., McElroy, M. B.: Three-dimensional climatological distribution of tropospheric $\mathrm{OH}$ : update and evaluation, J. Geophys. Res., 105, 8931-8980, 2000.

Stiller, G. P., von Clarmann, T., Haenel, F., Funke, B., Glatthor, N., Grabowski, U., Kellmann, S., Kiefer, M., Linden, A., Lossow, S., and López-Puertas, M.: Observed temporal evolution of global mean age of stratospheric air for the 2002 to 2010 period, Atmos. Chem. Phys., 12, 3311-3331, doi:10.5194/acp-12-3311-2012, 2012.

Strahan, S., Douglass, A., Stolarski, E., Akiyoshi, H., Bekki, S., Braesicke, P., Butchart, N., Chipperfield, M. P., Cugnet, D., Dhomse, S., Frith, S. M., Gettelman, A., Hardiman, S. C., Kinnison, D. E., Lamarque, J. F., Mancini, E., Marchand, M., Michou, M., Morgenstern, O., Nakamura, T., Olivie, D., Pawson, S., Pitari, G., Plummer, D. A., Pyle, J. A., Scinocca, J. F., Shepherd, T. G., Shibata, K., Smale, D., Teyssedre, H., Tian, W., and Yamashita, Y.: Using transport diagnostics to understand chemistry climate model ozone simulations, J. Geophys. Res., 116, D17302, doi:10.1029/2010JD015360, 2011.

Sussmann, R., Forster, F., Rettinger, M., and Bousquet, P.: Renewed methane increase for five years (2007-2011) observed by solar FTIR spectrometry, Atmos. Chem. Phys., 12, 48854891, doi:10.5194/acp-12-4885-2012, 2012.

Sussmann, R. and Rettinger, M.: TCCON data from Garmisch, Germany, Release GGG2014R0, TCCON data archive, hosted by the Carbon Dioxide Information Analysis Center, Oak Ridge National Laboratory, Oak Ridge, Tennessee, USA, doi:10.14291/tccon.ggg2014.garmisch01.R0/1149299, 2014.

Takigawa, M., Takahashi, M., and Akiyoshi, H.: Simulation of ozone and other chemical species using a Center for climate system research/national institute for environmental studies atmospheric GCM with coupled stratospheric chemistry, J. Geophys. Res., 104, 14003-14018, doi:10.1029/1998JD100105, 1999.

Turner, A. J., Jacob, D. J., Wecht, K. J., Maasakkers, J. D., Lundgren, E., Andrews, A. E., Biraud, S. C., Boesch, H., Bowman, K. W., Deutscher, N. M., Dubey, M. K., Griffith, D. W. T., Hase, F., Kuze, A., Notholt, J., Ohyama, H., Parker, R., Payne, V. H., Sussmann, R., Sweeney, C., Velazco, V. A., Warneke, T., Wennberg, P. O., and Wunch, D.: Estimating global

ACPD

15, 20395-20447, 2015

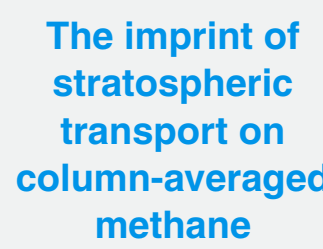

A. Ostler et al.

\section{Title Page}

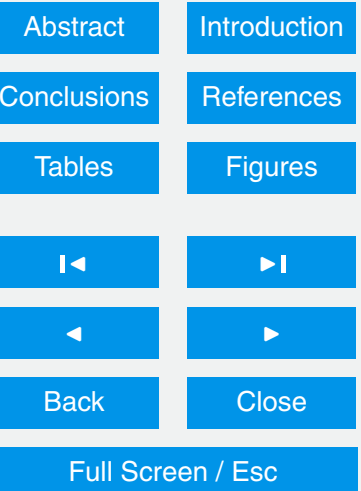

Printer-friendly Version

Interactive Discussion 
and North American methane emissions with high spatial resolution using GOSAT satellite data, Atmos. Chem. Phys., 15, 7049-7069, doi:10.5194/acp-15-7049-2015, 2015.

Volk, C. M., Elkins, J. W., Fahey, D. W., Dutton, G. S., Gilligan, J. M., Loewenstein, M., Podolske, J. R., Chan, K. R., and Gunson, M. R.: Evaluation of source gas lifetimes from stratospheric observations, J. Geophys. Res.-Atmos., 102, 25543-25564, doi:10.1029/97JD02215, 1997.

Warneke, T., Messerschmidt, J., Notholt, J., Weinzierl, C., Deutscher, N., Petri, C., Gruppe, P., Vuillemin, C., Truong, F., Schmidt, M., Ramonet, M., and Parmentier, E.: TCCON data from Orleans, France, Release GGG2014R0, TCCON data archive, hosted by the Carbon Dioxide Information Analysis Center, Oak Ridge National Laboratory, Oak Ridge, Tennessee, USA, doi:10.14291/tccon.ggg2014.orleans01.R0/1149276, 2014.

Washenfelder, R. A., Wennberg, P. O., and Toon, G. C.: Tropospheric methane retrieved from ground-based near-IR solar absorption spectra, Geophys. Res. Lett., 30, 2226, doi:10.1029/2003GL017969, 2003.

Waugh, D. W. and Hall, T. M., Age of stratospheric air: theory, observations, and models, Rev. Geophys., 40, 1010, doi:10.1029/2000RG000101, 2002.

Wecht, K. J., Jacob, D. J., Frankenberg, C., Jiang, Z., and Blake, D. R.: Mapping of North American methane emissions with high spatial resolution by inversion of SCIAMACHY satellite data, J. Geophys. Res.-Atmos., 119, 7741-7756, doi:10.1002/2014JD021551, 2014.

Wennberg, P. O., Wunch, D., Roehl, C., Blavier, J.-F., Toon, G. C., Allen, N., Dowell, P., Teske, K., Martin, C., and Martin, J.: TCCON data from Lamont, Oklahoma, USA, Release GGG2014R0, TCCON data archive, hosted by the Carbon Dioxide Information Analysis Center, Oak Ridge National Laboratory, Oak Ridge, Tennessee, USA, doi:10.14291/tccon.ggg2014.lamont01.R0/1149159, 2014a.

Wennberg, P. O., Roehl, C., Wunch, D., Toon, G. C., Blavier, J.-F., Washenfelder, R., Keppel-Aleks, G., Allen, N., and Ayers, J.: TCCON data from Park Falls, Wisconsin, USA, Release GGG2014R0, TCCON data archive, hosted by the Carbon Dioxide Information Analysis Center, Oak Ridge National Laboratory, Oak Ridge, Tennessee, USA, doi:10.14291/tccon.ggg2014.parkfalls01.R0/1149161, 2014b.

so Wunch, D., Toon, G. C., Wennberg, P. O., Wofsy, S. C., Stephens, B. B., Fischer, M. L., Uchino, O., Abshire, J. B., Bernath, P., Biraud, S. C., Blavier, J.-F. L., Boone, C., Bowman, K. P., Browell, E. V., Campos, T., Connor, B. J., Daube, B. C., Deutscher, N. M., Diao, M., Elkins, J. W., Gerbig, C., Gottlieb, E., Griffith, D. W. T., Hurst, D. F., Jiménez, R., Keppel-

\section{ACPD}

15, 20395-20447, 2015

\section{The imprint of stratospheric transport on \\ column-averaged methane \\ A. Ostler et al.}

\section{Title Page}

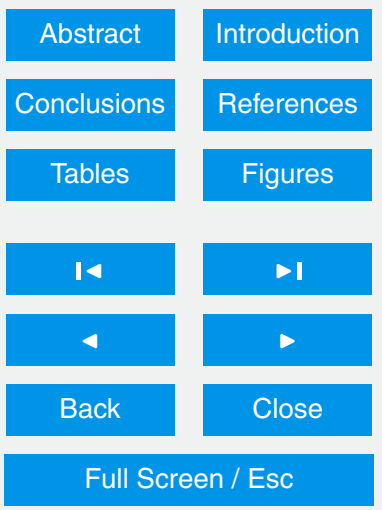

Printer-friendly Version

Interactive Discussion 
Aleks, G., Kort, E. A., Macatangay, R., Machida, T., Matsueda, H., Moore, F., Morino, I., Park, S., Robinson, J., Roehl, C. M., Sawa, Y., Sherlock, V., Sweeney, C., Tanaka, T., and Zondlo, M. A.: Calibration of the total carbon column observing network using aircraft profile data, Atmos. Meas. Tech., 3, 1351-1362, doi:10.5194/amt-3-1351-2010, 2010.

5 Wunch, D., Toon, G. C., Blavier, J.-F. L., Washenfelder, R. A., Notholt, J., Connor, B. J., Griffith, D. W. T., Sherlock, V., and Wennberg, P. O.: The total carbon column observing network, Phil. Trans. R. Soc. A, 369, 2087-2112, doi:10.1098/rsta.2010.0240, 2011.

\section{ACPD}

\section{5, 20395-20447, 2015}

\section{The imprint of stratospheric transport on column-averaged methane}

A. Ostler et al.

\section{Title Page}

\section{Abstract}

Conclusions

Tables

14

Full Screen / Esc

Printer-friendly Version

Interactive Discussion

Esc


Table 1. Overview of balloon flights where $\mathrm{SF}_{6}$ measurements were obtained to infer mean age of air data.

\begin{tabular}{llll}
\hline Balloon flight location & Latitude & Time & Altitude \\
\hline Hyderabad (India) & $17^{\circ} \mathrm{N}$ & 25 Mar 1987 & $6-34 \mathrm{~km}$ \\
Hyderabad (India) & $17^{\circ} \mathrm{N}$ & 16 Apr 1994 & $8-37 \mathrm{~km}$ \\
Aire sur l'Adour (France) & $44^{\circ} \mathrm{N}$ & 30 Sep 1993 & $6-34 \mathrm{~km}$ \\
Esrange (Sweden) & $68^{\circ} \mathrm{N}$ & 18 Jan 1992 & $6-34 \mathrm{~km}$ \\
Esrange (Sweden) & $68^{\circ} \mathrm{N}$ & 06 Feb 1992 & $6-34 \mathrm{~km}$ \\
Esrange (Sweden) & $68^{\circ} \mathrm{N}$ & 20 Mar 1992 & $6-34 \mathrm{~km}$ \\
Esrange (Sweden) & $68^{\circ} \mathrm{N}$ & 07 Mar 1995 & $6-34 \mathrm{~km}$ \\
\hline
\end{tabular}

\section{ACPD}

15, 20395-20447, 2015

\section{The imprint of stratospheric transport on column-averaged methane}

A. Ostler et al.

\section{Title Page}

\section{Abstract}

Conclusions

Tables

14

Back
Introduction

References

Figures

$>1$

Close

\section{Full Screen / Esc}

Printer-friendly Version

Interactive Discussion 


\section{ACPD}

Table 2. Overview of TCCON measurement sites used for evaluation of chemical transport model ACTM. Information on geographical location, the time period used for model-observation comparison, and the number of measurement days within the corresponding time period are provided.

\begin{tabular}{lllll}
\hline TCCON site & Latitude & Longitude & $\begin{array}{l}\text { Intercomparison } \\
\text { time period }\end{array}$ & $\begin{array}{l}\text { Measurements } \\
\text { (days) }\end{array}$ \\
\hline Sodankylä (Finland) & $67.4^{\circ} \mathrm{N}$ & $26.6^{\circ} \mathrm{E}$ & $2009-2013$ & 667 \\
Białystok (Poland) & $53.2^{\circ} \mathrm{N}$ & $23.0^{\circ} \mathrm{E}$ & $2009-2013$ & 558 \\
Karlsruhe (Germany) & $49.1^{\circ} \mathrm{N}$ & $8.4^{\circ} \mathrm{E}$ & $2009-2013$ & 459 \\
Orléans (France) & $48.0^{\circ} \mathrm{N}$ & $2.1^{\circ} \mathrm{E}$ & $2009-2013$ & 513 \\
Garmisch (Germany) & $47.5^{\circ} \mathrm{N}$ & $11.1^{\circ} \mathrm{E}$ & $2008-2013$ & 633 \\
Park Falls (USA) & $46.0^{\circ} \mathrm{N}$ & $90.3^{\circ} \mathrm{W}$ & $2008-2013$ & 1258 \\
Lamont (USA) & $36.6^{\circ} \mathrm{N}$ & $97.5^{\circ} \mathrm{W}$ & $2008-2013$ & 1407 \\
Saga (Japan) & $33.2^{\circ} \mathrm{N}$ & $130.3^{\circ} \mathrm{E}$ & $2011-2013$ & 276 \\
Izaña (Tenerife) & $28.3^{\circ} \mathrm{N}$ & $16.5^{\circ} \mathrm{W}$ & $2008-2013$ & 397 \\
Darwin (Australia) & $12.4^{\circ} \mathrm{S}$ & $130.9^{\circ} \mathrm{E}$ & $2008-2013$ & 1133 \\
Reunion (Reunion Island) & $20.9^{\circ} \mathrm{S}$ & $55.5^{\circ} \mathrm{E}$ & $2011-2013$ & 396 \\
Wollongong (Australia) & $34.4^{\circ} \mathrm{S}$ & $150.9^{\circ} \mathrm{E}$ & $2008-2013$ & 752 \\
Lauder (New Zealand) & $45.0^{\circ} \mathrm{S}$ & $169.7^{\circ} \mathrm{E}$ & $2008-2013$ & 870 \\
\hline
\end{tabular}

\section{The imprint of stratospheric transport on \\ column-averaged methane}

A. Ostler et al.

\section{Title Page}

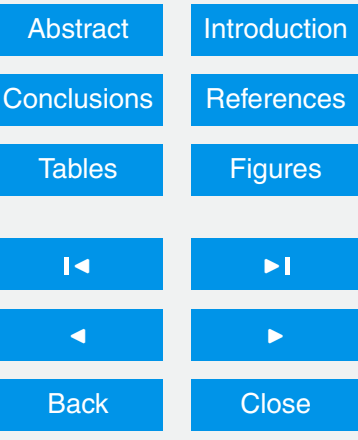

Full Screen / Esc

Printer-friendly Version

Interactive Discussion 

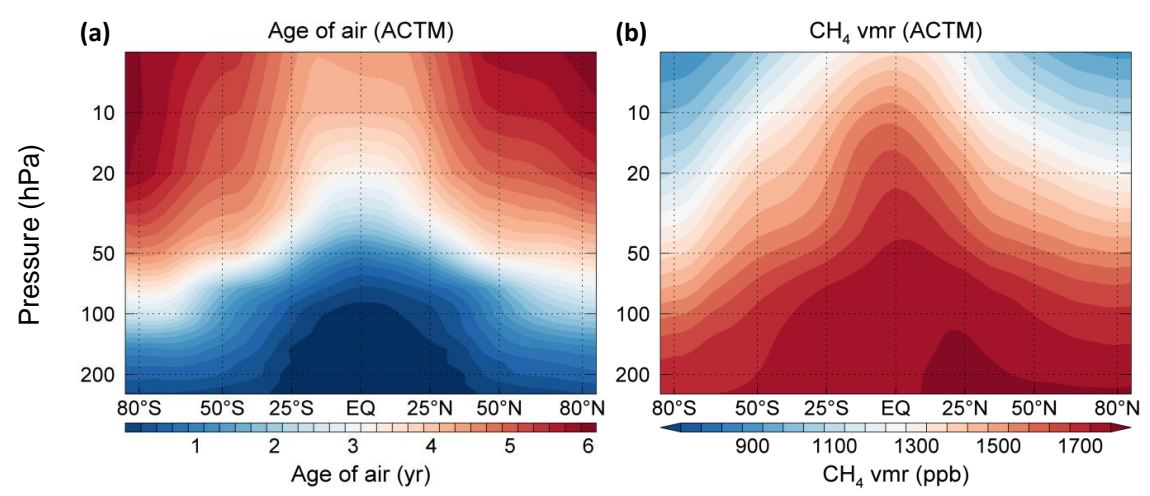

\section{ACPD}

15, 20395-20447, 2015

\section{The imprint of stratospheric transport on column-averaged methane}

\section{A. Ostler et al.}

\section{Title Page}
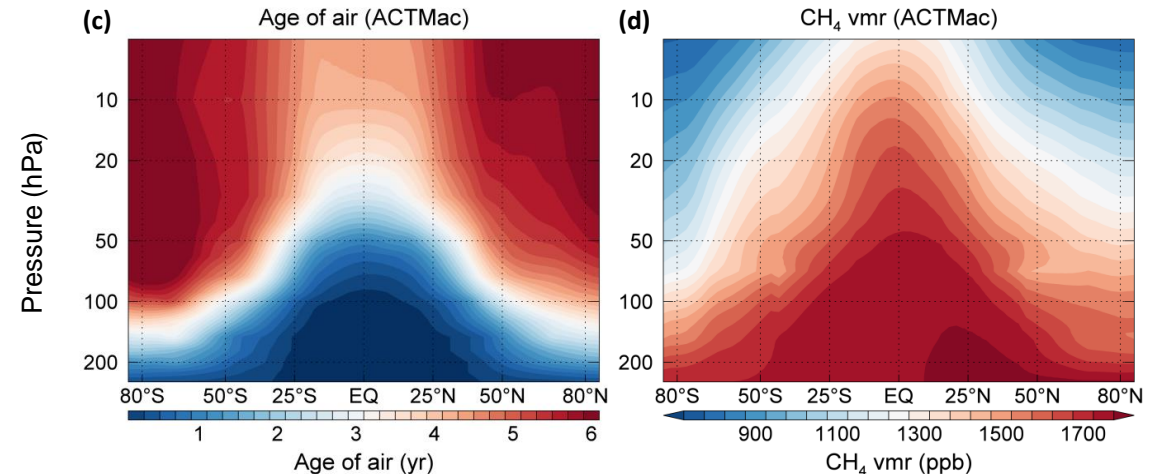

Figure 1.

\section{Abstract}

Conclusions

Tables

14

Back

Full Screen / Esc

Printer-friendly Version 

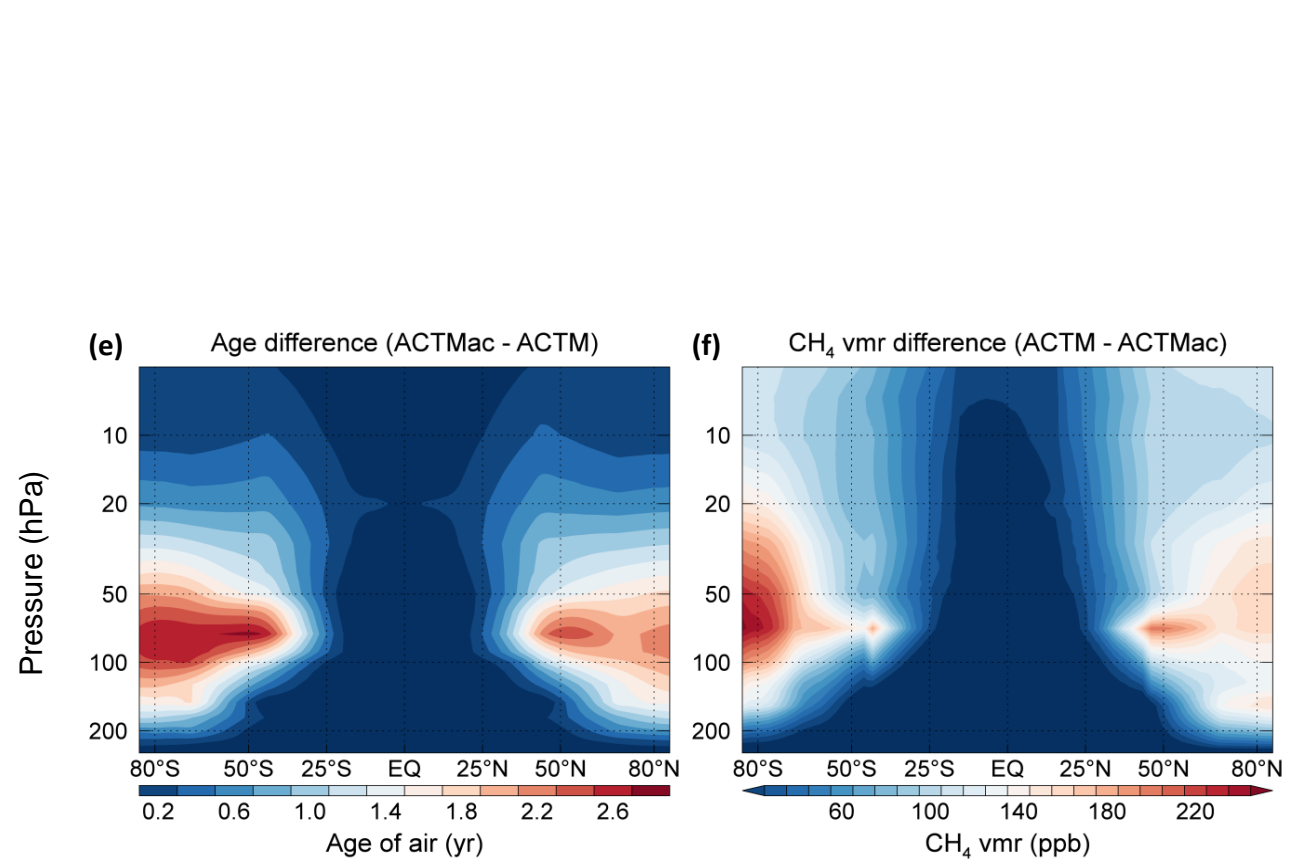

Figure 1. Impact of stratospheric transport on zonal mean distributions of $\mathrm{CH}_{4}$. Zonal vertical distributions of mean age in years (yr) and of $\mathrm{CH}_{4}$ volume mixing ratios (vmr) in parts per billion (ppb), respectively. Original model distributions (ACTM; a, b) were corrected to account for errors in stratospheric transport (ACTMac; c, d). The differences are shown in the lower trace (e, f). Age distributions and $\mathrm{CH}_{4}$ distributions are annual means for the year 2009.

\section{ACPD}

\section{The imprint of stratospheric transport on column-averaged methane}

\section{A. Ostler et al.}

\section{Title Page}

\section{Abstract}

Introduction

Conclusions

References

Tables

Figures

14

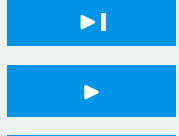

Back

Close 

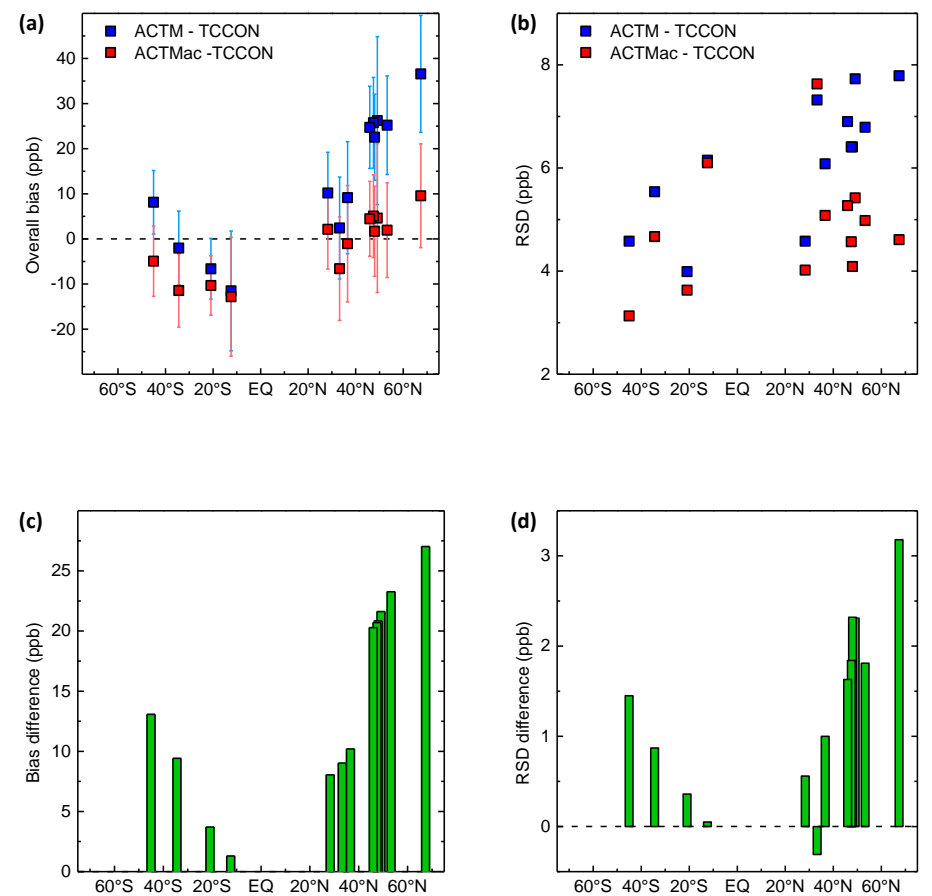

Figure 2. Impact of stratospheric transport on the overall and seasonal agreement between modeled and observed $\mathrm{CH}_{4}$ at TCCON sites. The overall bias (a) is calculated from deseasonalized model-observation differences of column-averaged dry-air $\mathrm{CH}_{4}$ mixing ratios $\left(\mathrm{XCH}_{4}\right)$ for selected TCCON sites indexed by geographical latitude. Error bars are $2 \sigma$ standard deviations. The residual standard deviation (RSD) (b) is calculated from detrended model-observation $\mathrm{XCH}_{4}$ differences. The difference between bias related to ACTM, and to ACTMac is shown as bias difference (c), respectively. The difference between residual standard deviations related to ACTM and to ACTMac is shown in the lower trace (d); XCH4 biases, residual standard deviations, and corresponding differences in parts per billion (ppb).
ACPD

15, 20395-20447, 2015

\section{The imprint of stratospheric \\ transport on \\ column-averaged methane}

A. Ostler et al.

\section{Title Page}

\section{Abstract}

Conclusions

Tables

14

Back

\section{Introduction}

References

Figures

$\Delta$

\section{Full Screen / Esc}

Printer-friendly Version

Interactive Discussion 
(a)

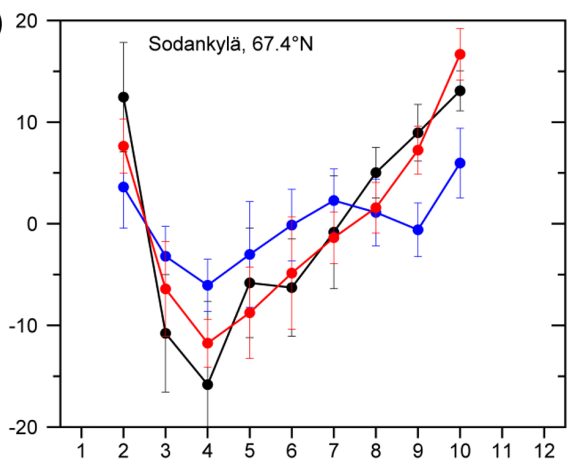

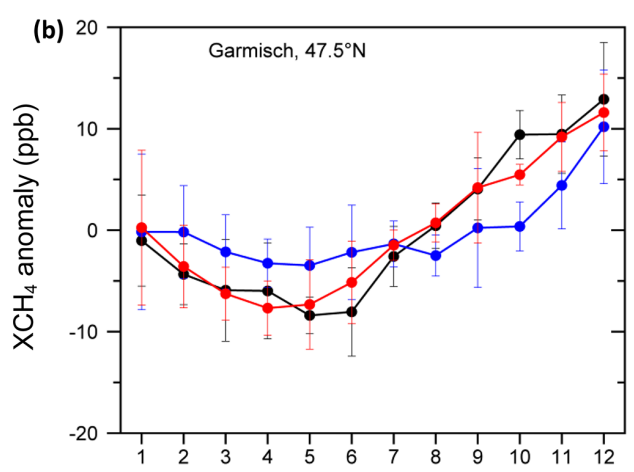

(c)

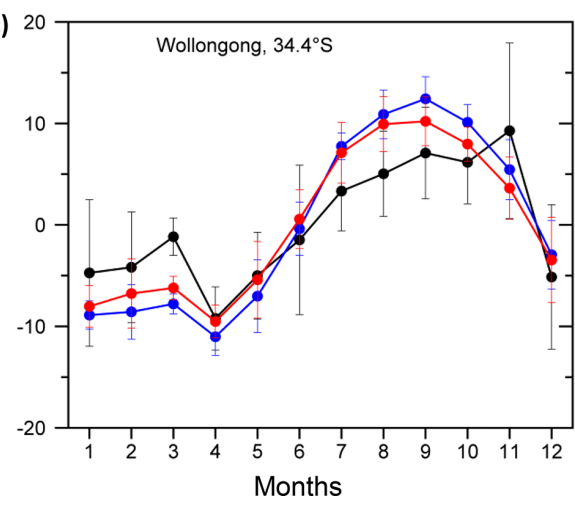

Figure 3. Contribution of stratospheric transport on mean seasonal anomalies of $\mathrm{CH}_{4}$. Mean seasonal cycles are calculated from climatological monthly means of detrended $\mathrm{XCH}_{4}$ time series for ACTM (blue), ACTMac (red), and TCCON (black), respectively. Error bars are $2 \sigma$ standard errors; $\mathrm{XCH}_{4}$ in parts per billion (ppb). Mean seasonal cycles are provided for arctic region (a), for midlatitudes (b), and for subtropics (c). Mean seasonal cycles from remaining TCCON sites are shown in Fig. B1.
ACPD

15, 20395-20447, 2015

\section{The imprint of stratospheric transport on column-averaged methane}

A. Ostler et al.

\section{Title Page}

\section{Abstract}

Conclusions

Tables

14

\section{Full Screen / Esc}

Printer-friendly Version

Interactive Discussion 


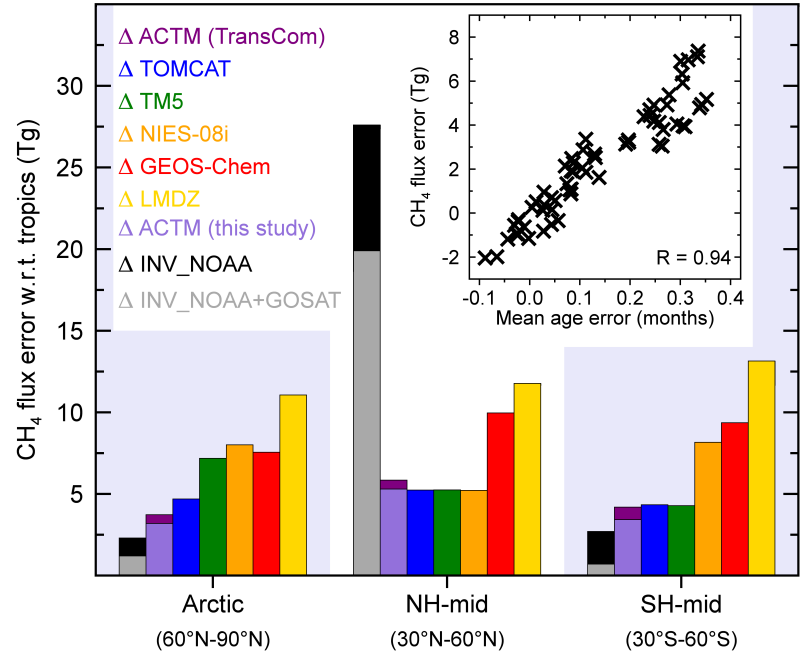

Figure 4. Impact of errors in stratospheric model transport on inverted $\mathrm{CH}_{4}$ fluxes. Zonal $\mathrm{CH}_{4}$ emission adjustments caused by stratospheric model-transport error for six CTMs used in the TransCom-CH4 comparison (TM5, TOMCAT, NIES-08i, ACTM, LMDZ, GEOS-Chem), and for ACTM used in this study. In addition, two distributions of inversion-estimated emission adjustments (INV_NOAA, INV_NOAA+GOSAT; see Table 5 of Alexe et al., 2015) are provided for reference. INV_NOAA uses surface measurements only, whereas INV_NOAA+GOSAT is based on both surface and satellite observations. $\mathrm{CH}_{4}$ emission adjustments are twoyear averages (TransCom CTMs: 2006 and 2007; ACTM: 2008 and 2009; INV_NOAA and INV_NOAA+GOSAT: 2010 and 2011). The inset to Fig. 4 shows the correlation of flux errors and mean age errors relative to the tropics aggregated for $10^{\circ}$ latitude bands (i.e. one point corresponds to one latitude band and one CTM). The age error is integrated with respect to sigma-pressure and scaled by the relative fraction of the zonal region to the total Earth surface. Note that the flux adjustments in the main figure are aggregated for $30^{\circ}$ latitude bands because of clarity.
ACPD

15, 20395-20447, 2015

\section{The imprint of stratospheric transport on \\ column-averaged methane}

A. Ostler et al.

\section{Title Page}

\section{Abstract}

Conclusions

Tables

14

Back

\section{Introduction}

References

Figures

$\Delta$

\section{Full Screen / Esc}

Printer-friendly Version

Interactive Discussion 


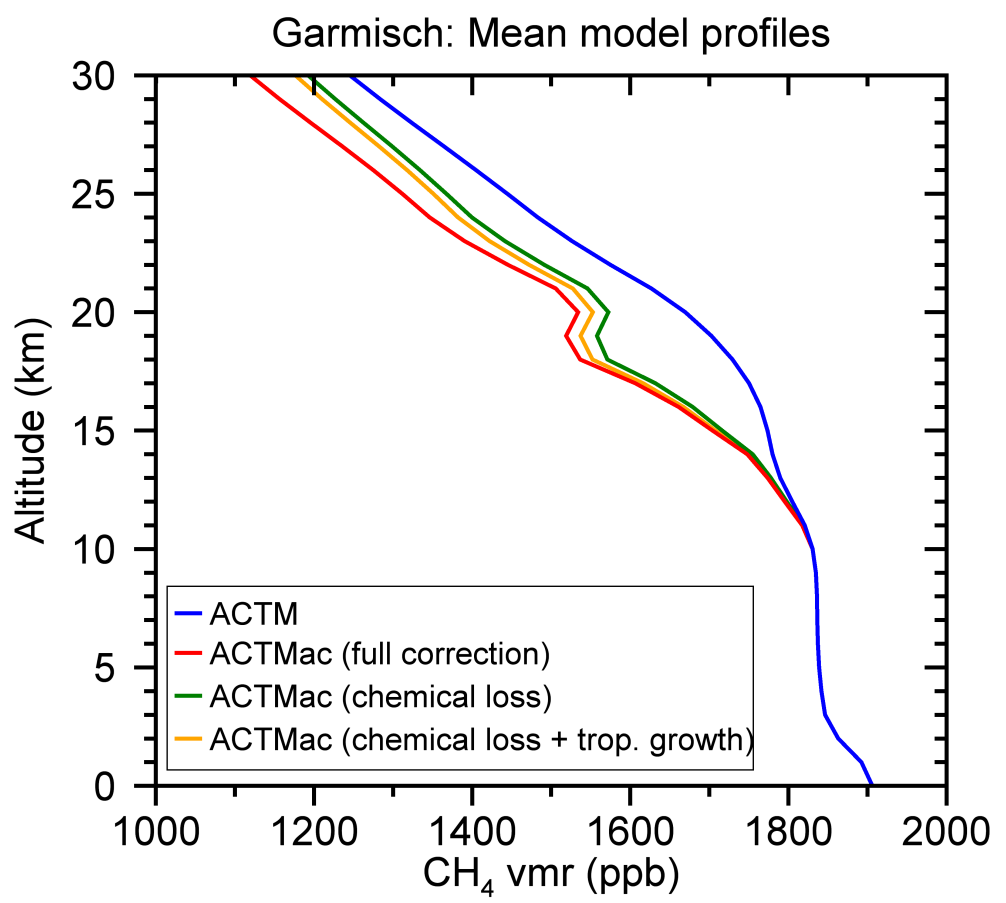

15, 20395-20447, 2015

The imprint of stratospheric transport on

column-averaged methane

A. Ostler et al.

\section{Title Page}

\section{Abstract}

Conclusions

Tables

14

Full Screen / Esc

Printer-friendly Version

Interactive Discussion 

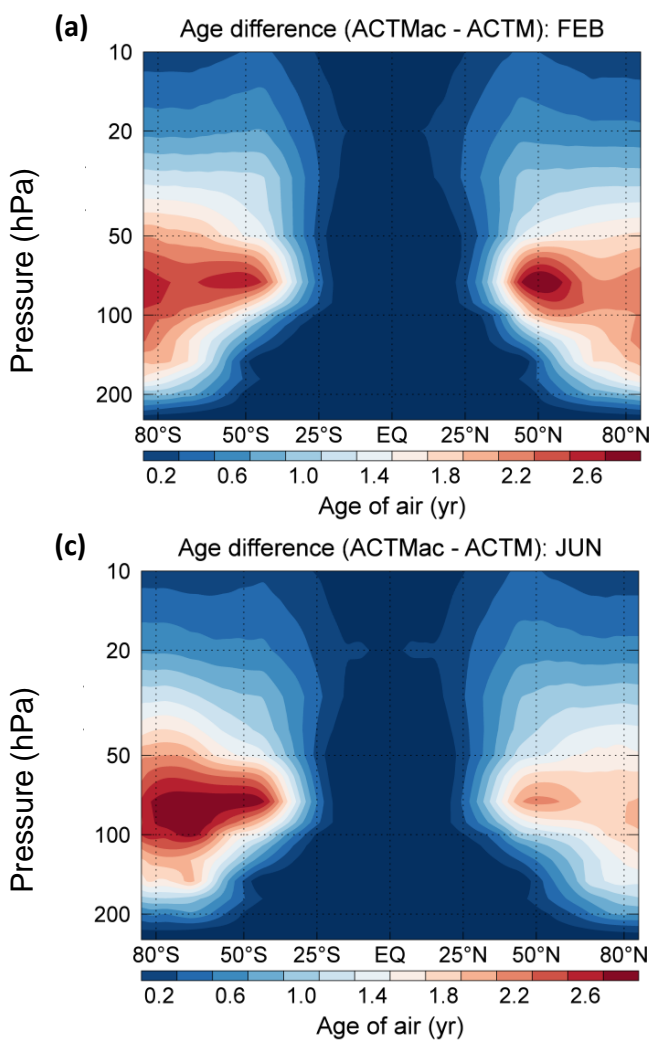

(b) $\mathrm{CH}_{4}$ vmr difference (ACTM - ACTMac): FEB

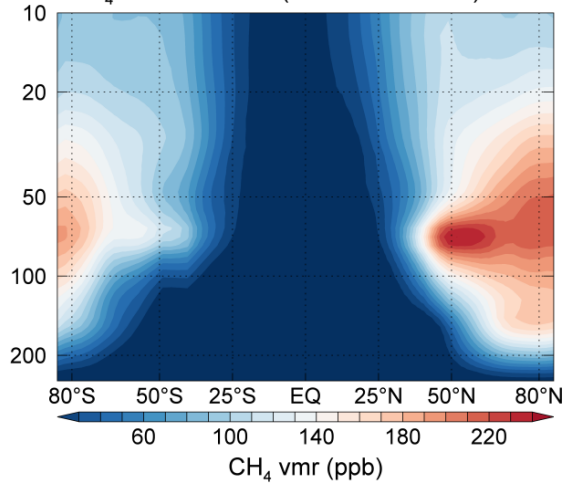

(d)

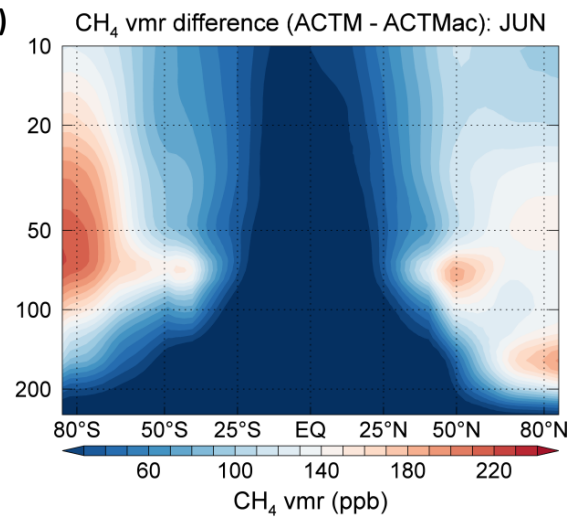

Figure A2.

\section{ACPD}

15, 20395-20447, 2015

\section{The imprint of stratospheric transport on column-averaged methane}

\section{A. Ostler et al.}

\section{Title Page}

\section{Abstract}

Introduction

Conclusions

References

Tables

Figures

14

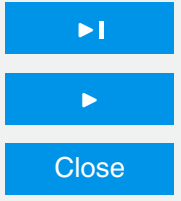

Back

Full Screen / Esc

Printer-friendly Version

Interactive Discussion 

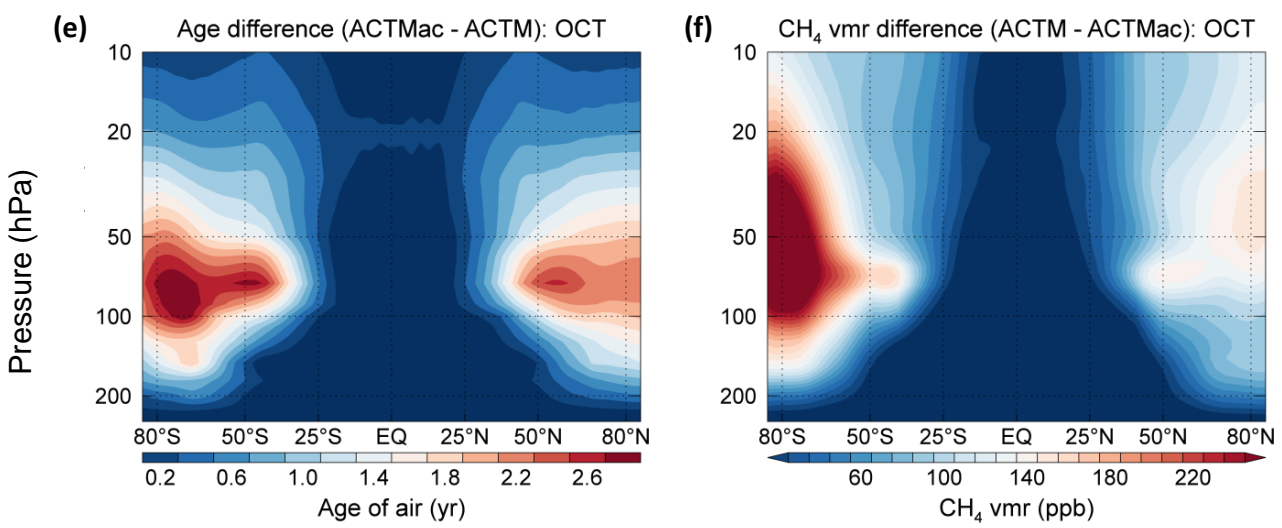

Figure A2. Seasonal impact of stratospheric transport correction on zonal mean distributions of $\mathrm{CH}_{4}$. As Fig. 1, but only difference distributions of mean age in years (yr), and of $\mathrm{CH}_{4}$ volume mixing ratios (vmr) in parts per billion (ppb), respectively. Age distributions and $\mathrm{CH}_{4}$ distributions are monthly means for the year 2009. Zonal distributions corresponding to different months (February: a, b; June: c, d; October: e, f) reflect the seasonal variation of the stratospheric model-transport error.

\section{The imprint of stratospheric transport on column-averaged methane}

\section{A. Ostler et al.}

\section{Title Page}

\section{Abstract}

Introduction

Conclusions

References

Tables

Figures

14

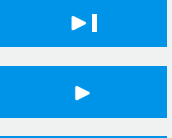

Back

Close 


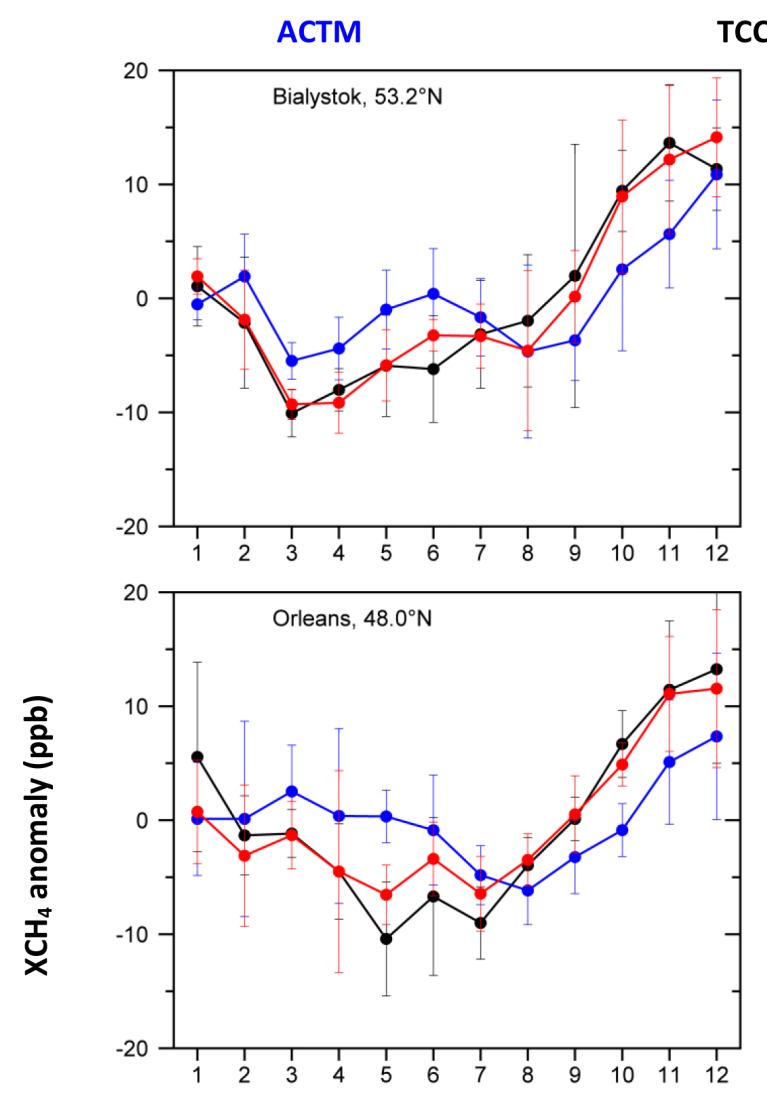

TCCON
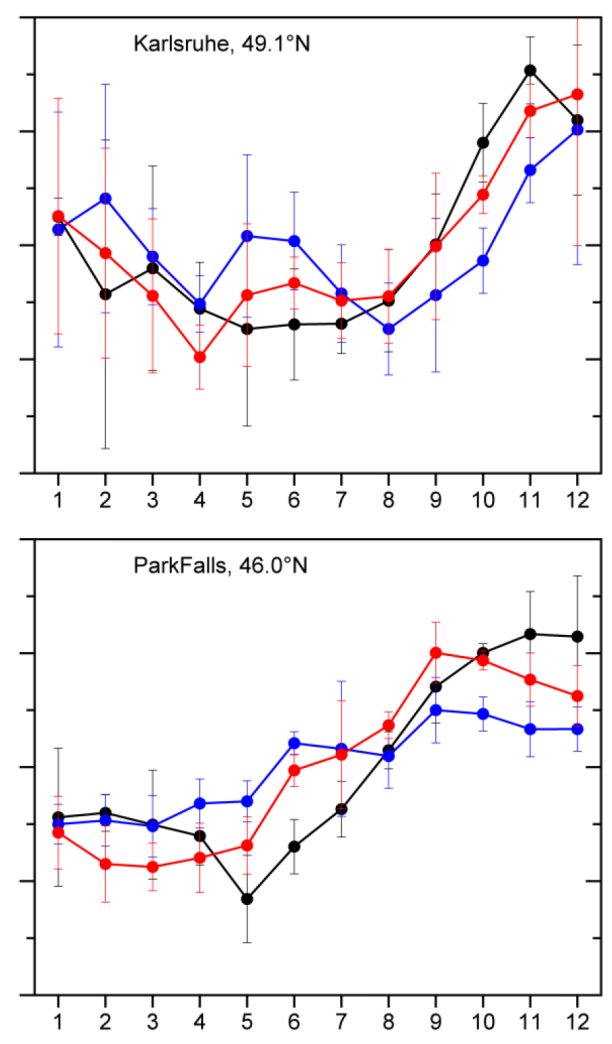

ACPD

15, 20395-20447, 2015

The imprint of stratospheric transport on column-averaged methane

\section{A. Ostler et al.}

\section{Title Page}

\section{Abstract}

Introduction

Conclusions

References

Tables

\section{Figures}

14

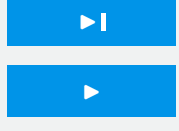

Back

Close

\section{Full Screen / Esc}

Printer-friendly Version

Interactive Discussion 

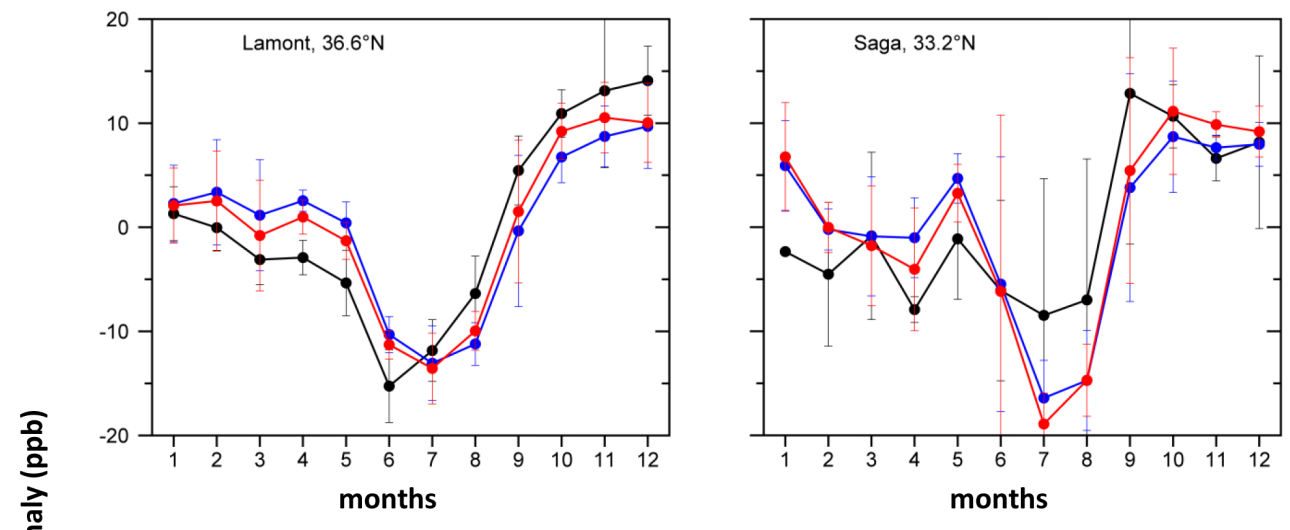

\section{ACPD}

15, 20395-20447, 2015

The imprint of stratospheric transport on column-averaged methane

\section{A. Ostler et al.}

\section{Title Page}

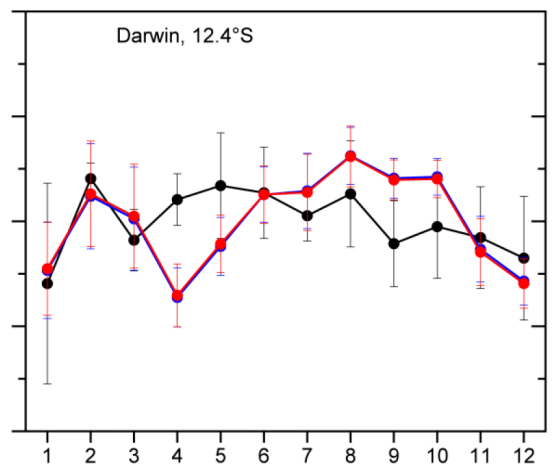

Abstract

Introduction

Conclusions

References

Tables

Figures

14

Full Screen / Esc

Printer-friendly Version

Interactive Discussion 

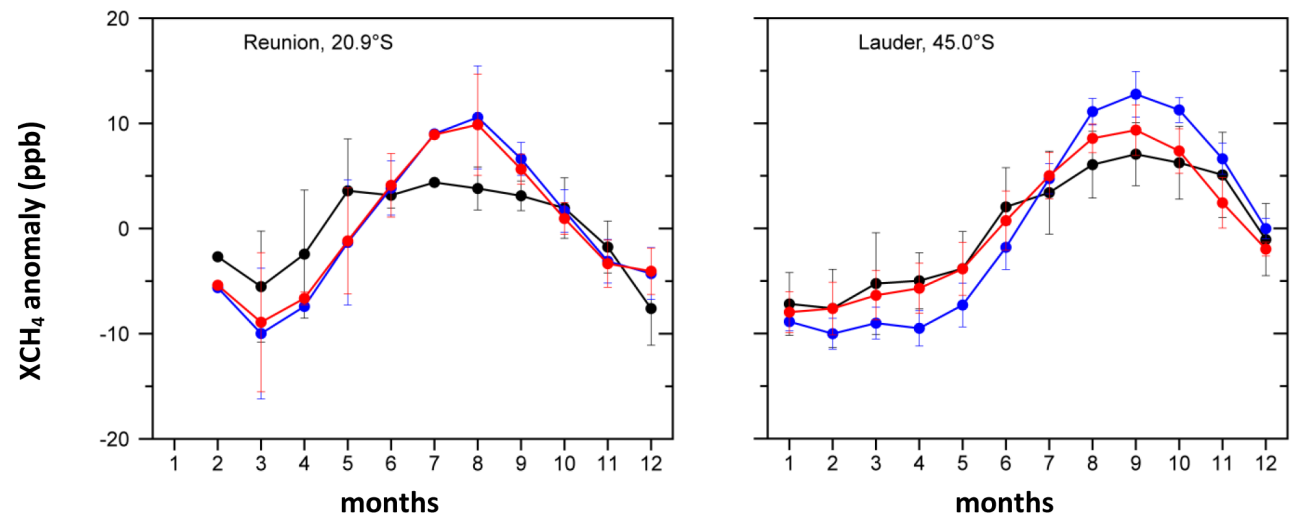

\section{ACPD}

15, 20395-20447, 2015

\section{The imprint of stratospheric transport on column-averaged methane}

\section{A. Ostler et al.}

\section{Title Page}

\section{Abstract}

Conclusions

Tables

14

Full Screen / Esc

Printer-friendly Version

Interactive Discussion 

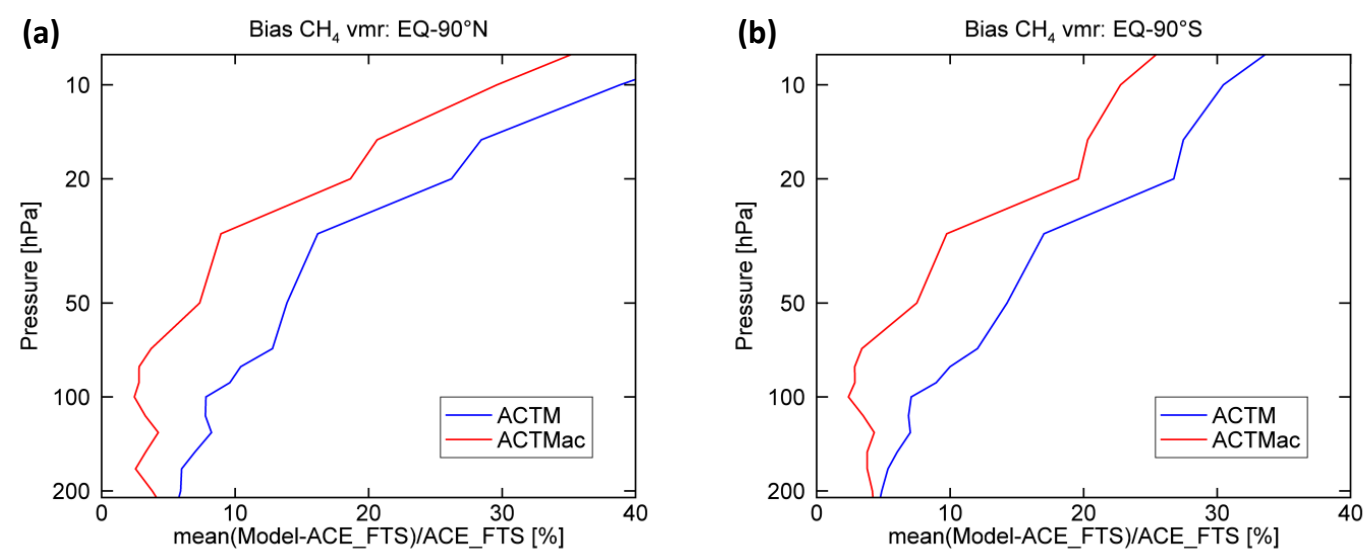

\section{ACPD}

15, 20395-20447, 2015

\section{The imprint of stratospheric transport on column-averaged methane}

A. Ostler et al.

\section{Title Page}
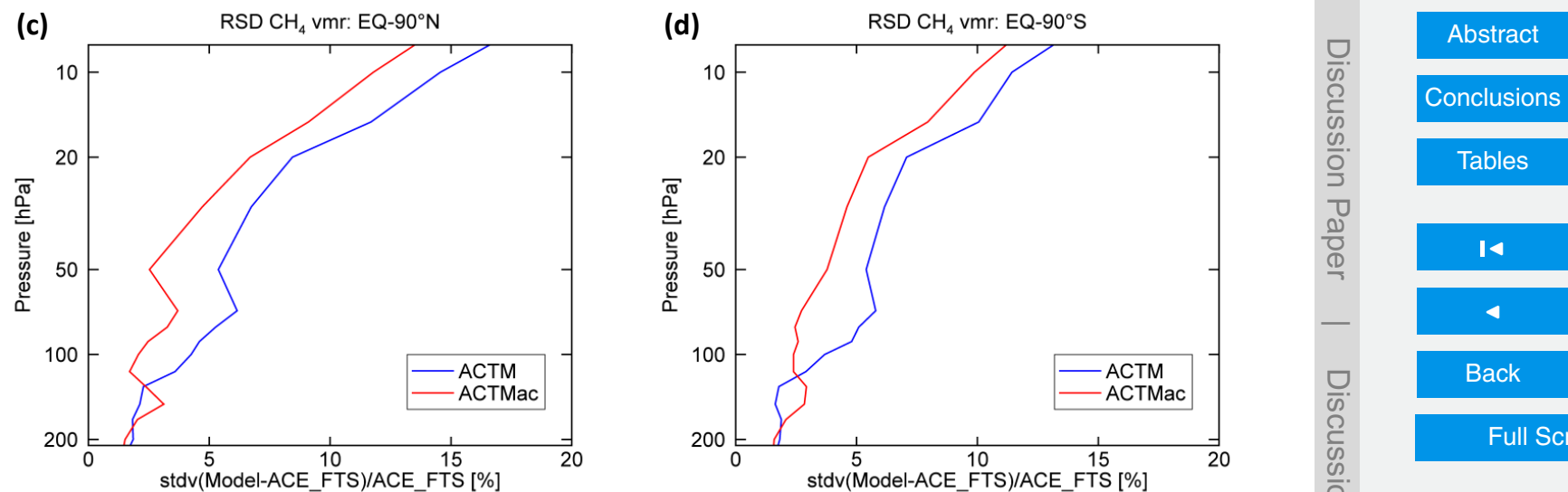

Introduction

References

\section{Figures}

\section{Full Screen / Esc}

Printer-friendly Version

\section{Figure $\mathbf{C 1}$.}




\section{ACPD}

15, 20395-20447, 2015
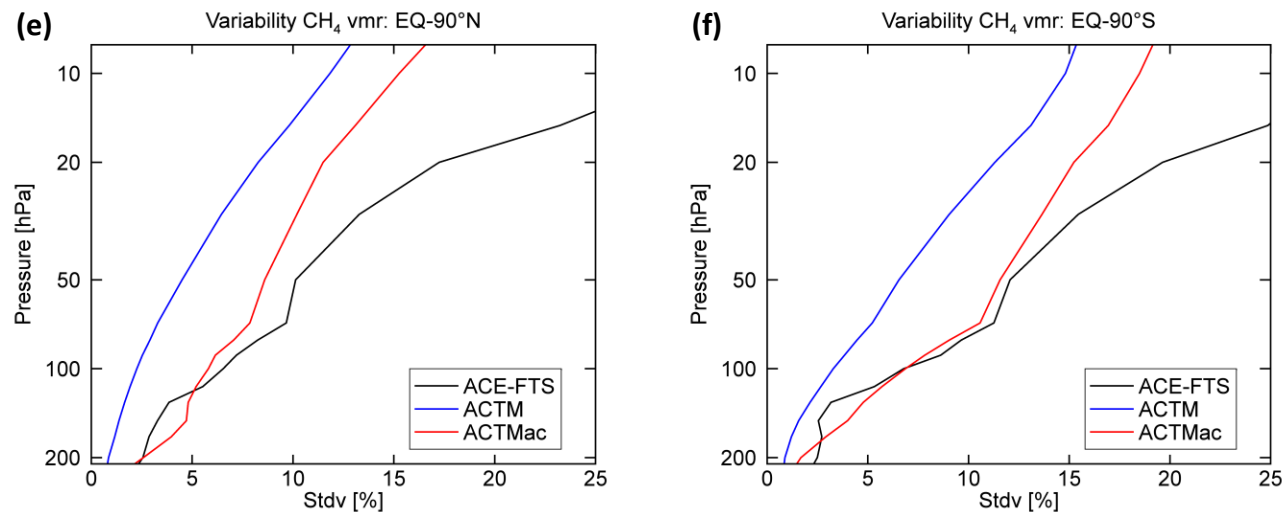

\section{The imprint of stratospheric transport on column-averaged methane}

A. Ostler et al.

\section{Title Page}

\section{Abstract}

Conclusions

Tables

14

Figure C1. Statistical evaluation of latitude-height agreement between multi-annual stratodeviations (c, d) are derived from monthly differences between model (two-year average: 2008, 2009) and ACE-FTS $\mathrm{CH}_{4}$ vmr as a function of altitude (pressure) for both hemispheres. Individual standard deviations $(\mathbf{e}, \mathbf{f})$ from $\mathrm{CH}_{4}$ vertical distributions reflect atmospheric variability.

Full Screen / Esc

Printer-friendly Version

Interactive Discussion 

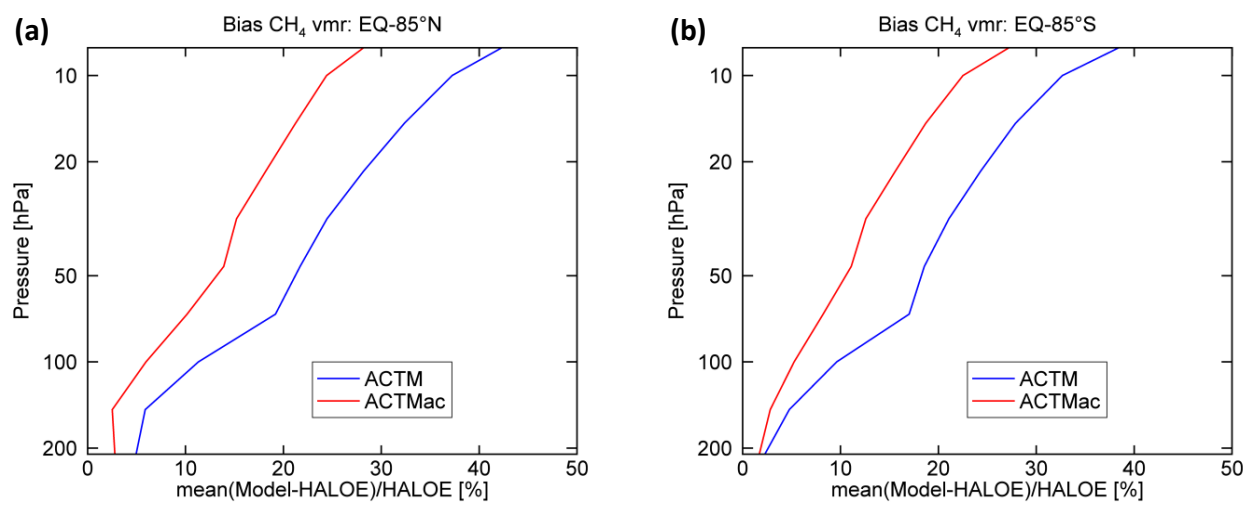

\section{ACPD}

15, 20395-20447, 2015

\section{The imprint of stratospheric transport on column-averaged methane}

A. Ostler et al.

\section{Title Page}
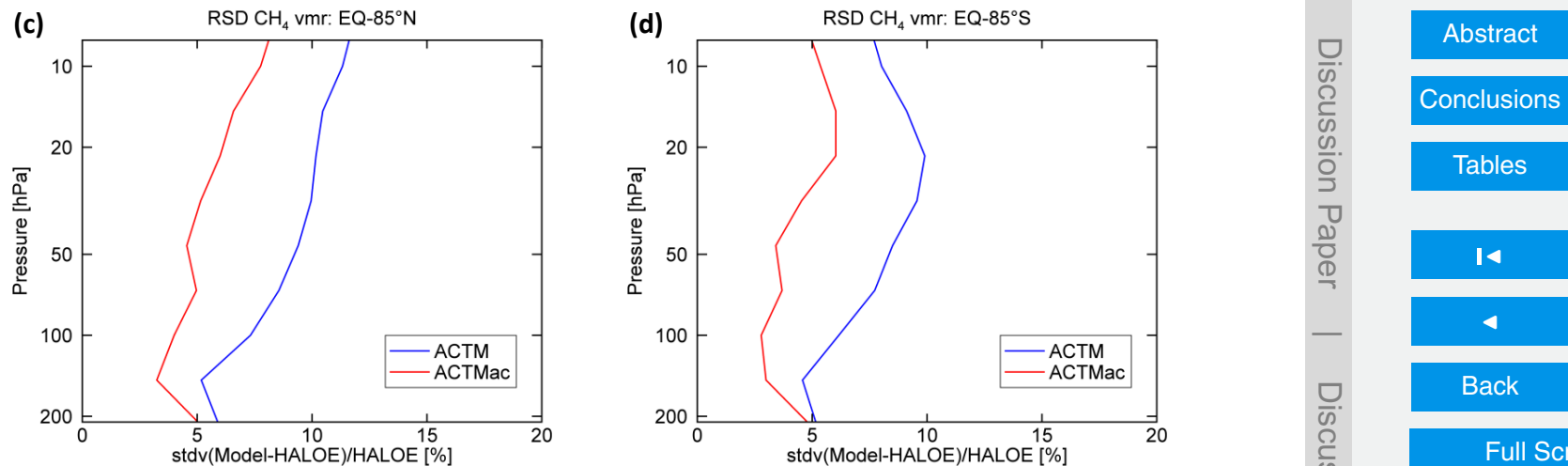

Introduction

References

Figures

\section{Full Screen / Esc}

Printer-friendly Version

Interactive Discussion 

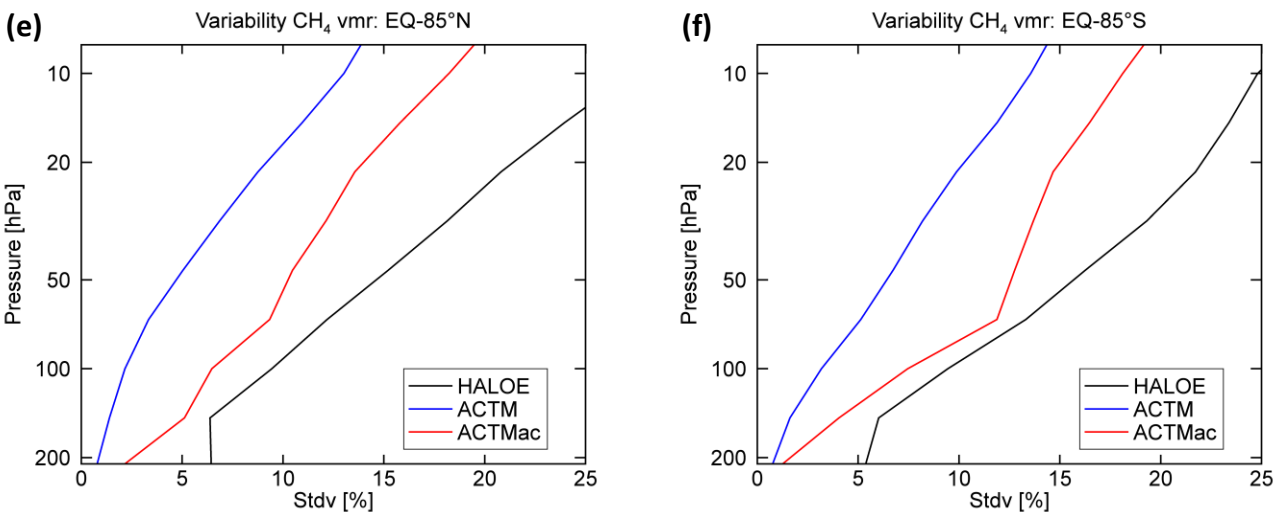

\section{ACPD}

15, 20395-20447, 2015

\section{The imprint of stratospheric transport on \\ column-averaged methane}

\section{A. Ostler et al.}

\section{Title Page}

\section{Abstract}

Conclusions

Tables

14

Back
Introduction

References

Figures

Close

Full Screen / Esc

Printer-friendly Version

Interactive Discussion 

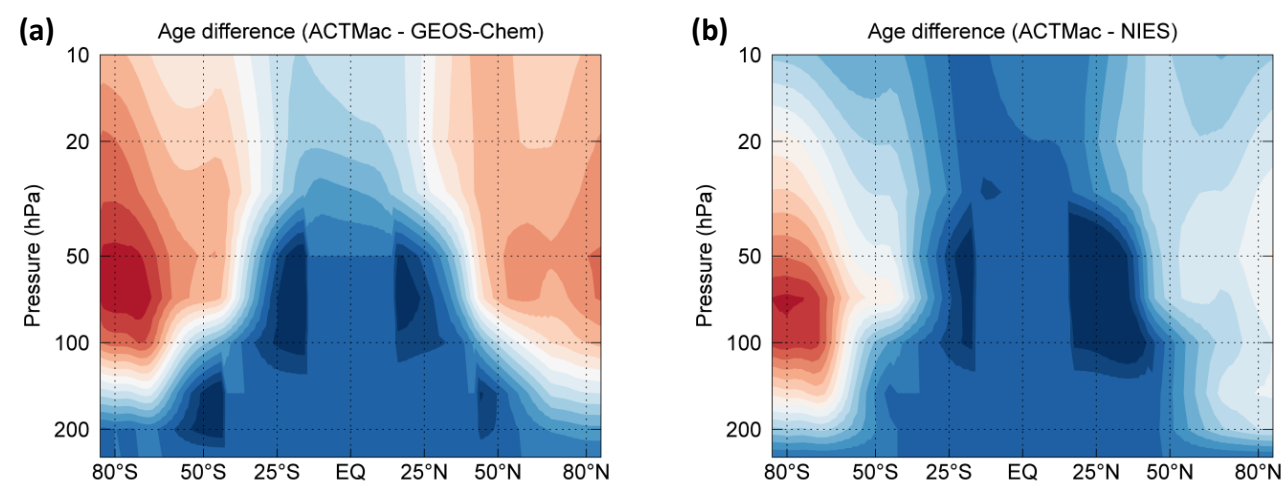

\section{ACPD}

15, 20395-20447, 2015

\section{The imprint of stratospheric transport on column-averaged methane}

\section{A. Ostler et al.}

\section{Title Page}
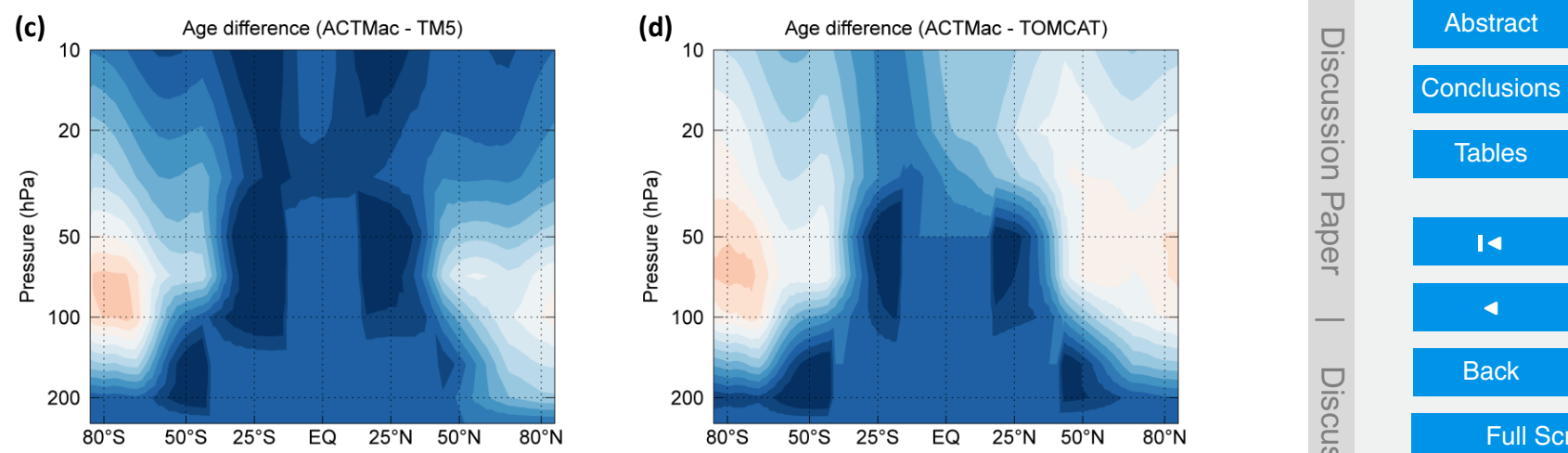

Introduction

References

Back

Figures

Full Screen / Esc

Printer-friendly Version

Interactive Discussion 

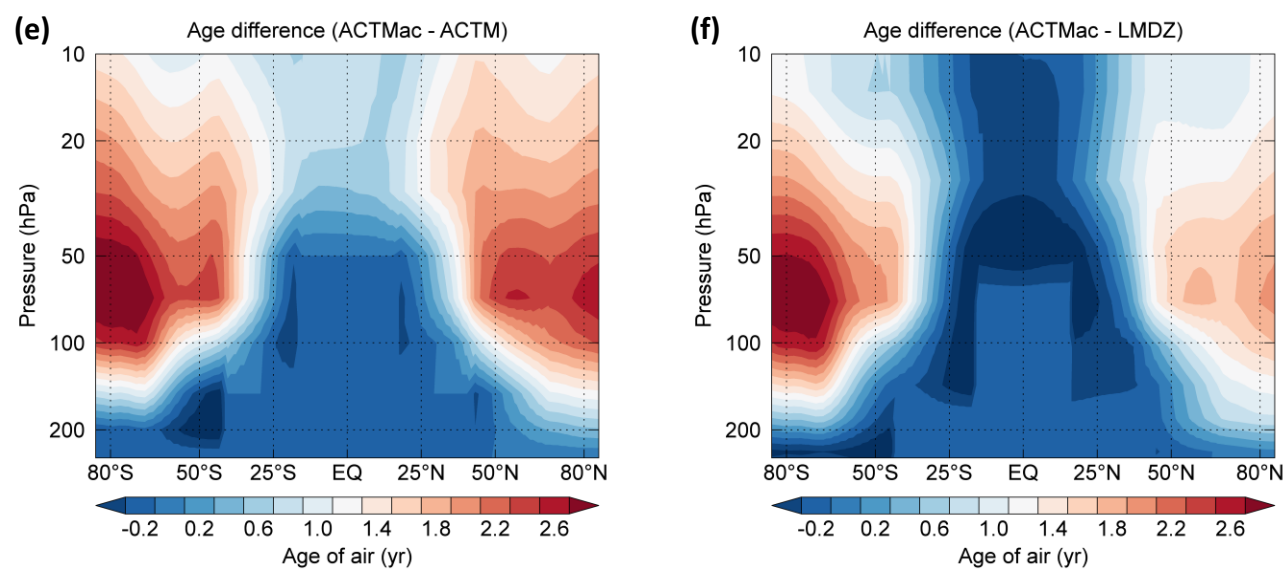

\section{ACPD}

15, 20395-20447, 2015

\section{The imprint of stratospheric transport on \\ column-averaged methane}

\section{A. Ostler et al.}

\section{Title Page}

\section{Abstract}

Conclusions

Tables

14

Back

\section{Full Screen / Esc}

Printer-friendly Version

Interactive Discussion 

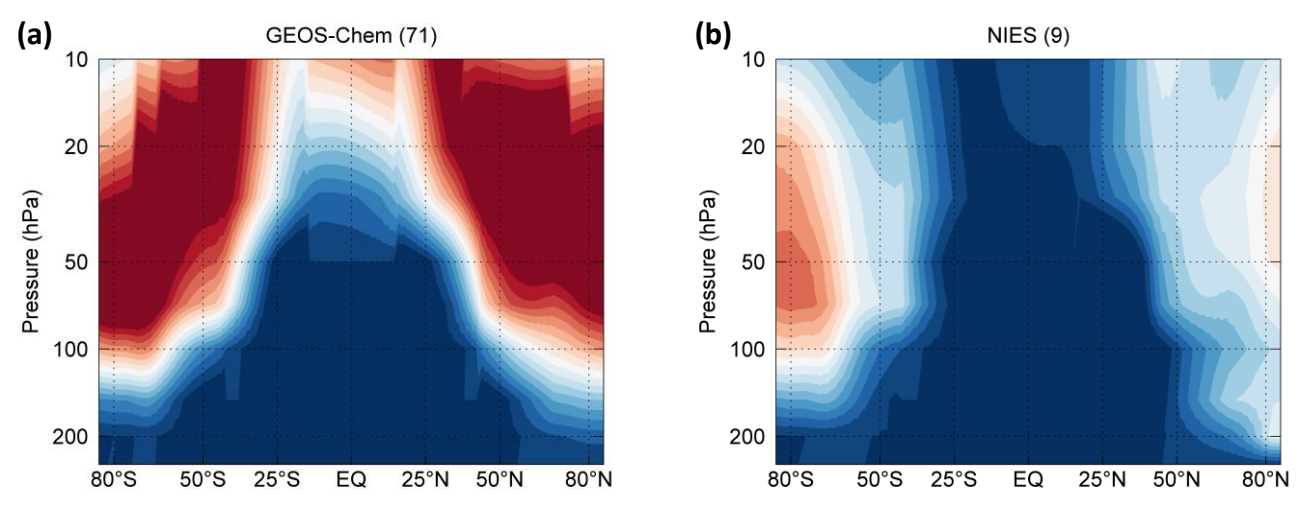

\section{ACPD}

15, 20395-20447, 2015

\section{The imprint of stratospheric transport on column-averaged methane}

\section{A. Ostler et al.}

\section{Title Page}
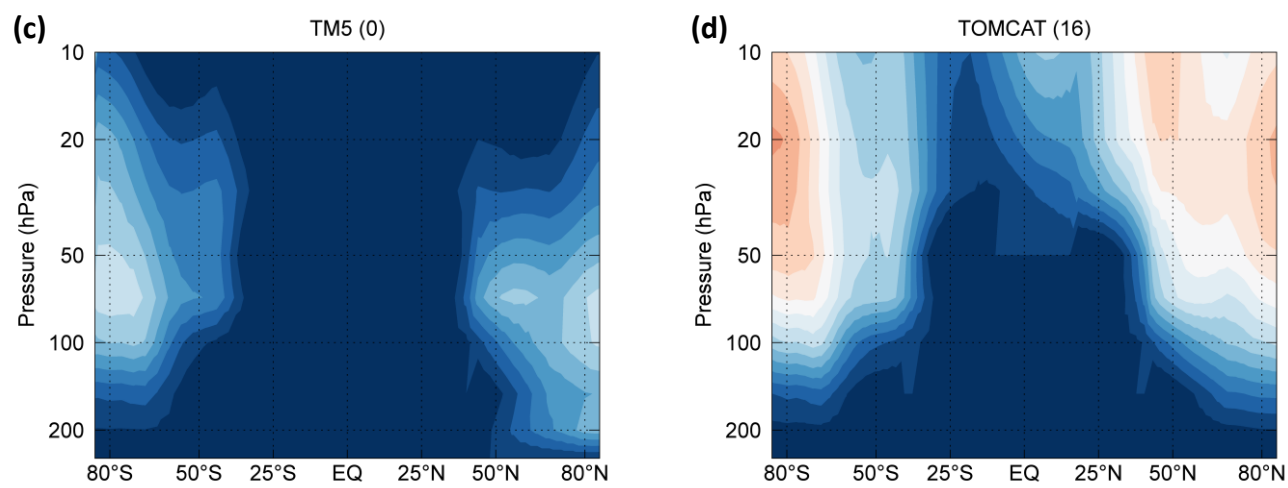

Figure D2.

\section{Abstract}

Introduction

Conclusions

References

Tables

Figures

14

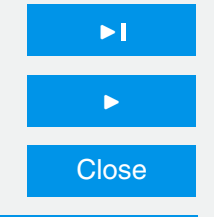

Back

Full Screen / Esc

Printer-friendly Version

Interactive Discussion 

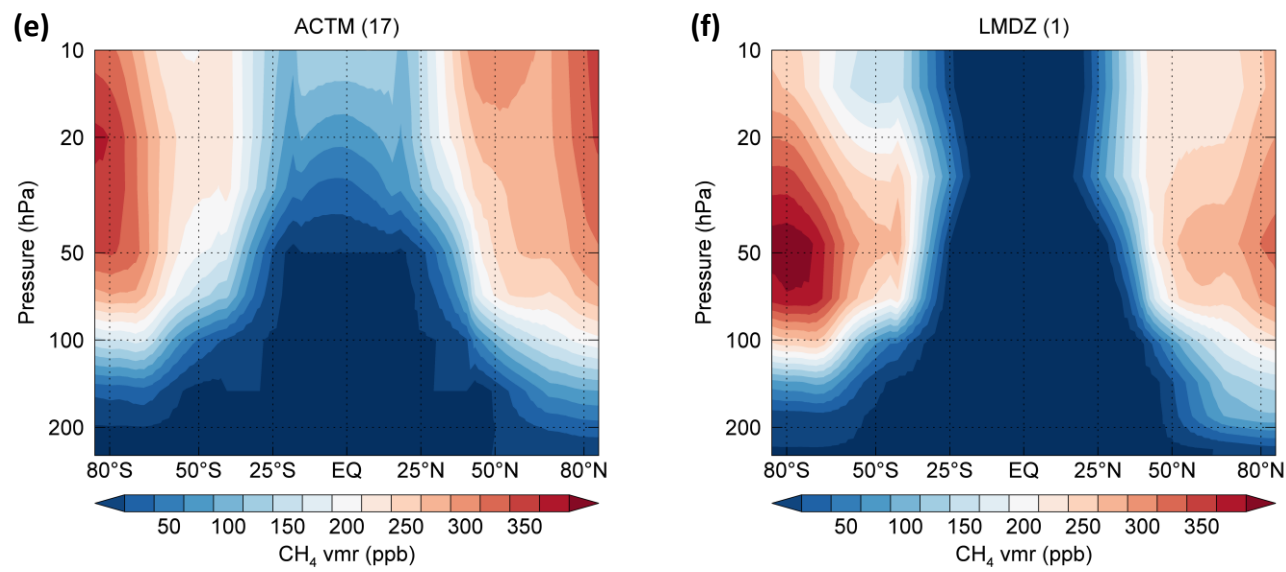

\section{ACPD}

15, 20395-20447, 2015

\section{The imprint of stratospheric transport on \\ column-averaged methane}

\section{A. Ostler et al.}

\section{Title Page}

\section{Abstract}

Conclusions

Tables

14

Back

Full Screen / Esc

Printer-friendly Version

Interactive Discussion 